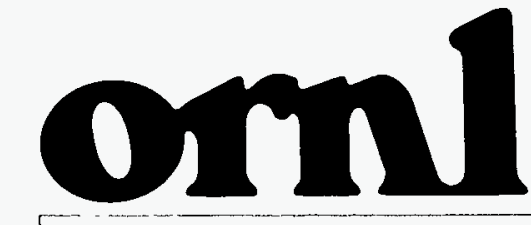

OAK RIDGE NATIONAL LABORATORY

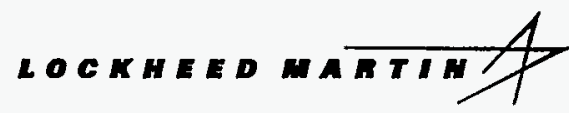

MANAGED AND OPERATED BY LOCKHEED MARTN ENERGY RESEARCH CORPORATION FOR THE UNTED STATES DEPARTIUENT OF ENERGY

ORNL-27 (3-96)
ORNL/TM-13223
Radiological Dose Assessment

of Department of Energy Pinellas Plant

Waste

Proposed for Disposal at

United States Pollution Control, Inc. in Tooele County, Utah

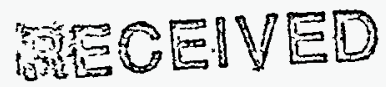

M. L. Socolof ${ }^{l}$

D. W. Lee'

D. C. Kocher ${ }^{2}$

Ayb 27 1296

O S

\footnotetext{
'Energy Division

${ }^{2}$ Health Sciences Research Division

Oak Ridge National Laboratory

Oak Ridge, Tennessee 37831
}

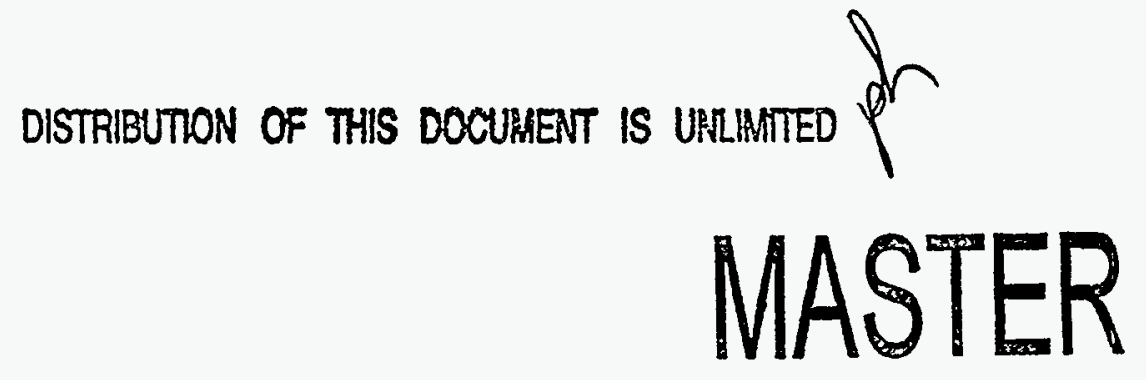


This report has been reproduced directly from the best available copy.

Available to DOE and DOE contractors from the Office of Scientific and Technical Information, P.O. Box 62, Oak Ridge, TN 37831; prices available from (615) 576-8401, FTS 626-8401.

Available to the public from the National Technical Information Service, U.S. Department of Commerce, 4284 Port Royal Rd., Springfield, VA 22161.

This report was prepared as an account of work sponsored by an agency of United States Government. Neither the United States Government nor any agency thereof, nor any of their employees, makes any warranty, express or implied, or assumes any legal liability or responsibility for the accuracy, completeness, or usefulness of any information, apparatus, product, or process disclosed, or represents that its use would not infringe privately owned rights. Reference herein to any specific commercial product, process, or service by trade name, trademark, manufacturer, or otherwise, does not necessarily constitute or imply its endorsement, recommendation, or favoring by the United States Government or any agency thereof. The views and opinions of authors expressed herein do not necessarily state or reflect those of the United States Government or any agency thereof. 
ORNL/TM-13223

\title{
Radiological Dose Assessment of Department of Energy Pinellas Plant Waste Proposed for Disposal at United States Pollution Control, Inc. in Tooele County, Utah
}

\author{
M. L. Socolof ${ }^{1}$ \\ D. W. Lee \\ D. C. Kocher ${ }^{2}$ \\ ${ }^{1}$ Energy Division \\ ${ }^{2}$ Health Sciences Research Division \\ Oak Ridge National Laboratory \\ Oak Ridge, Tennessee 37831 \\ April 1996

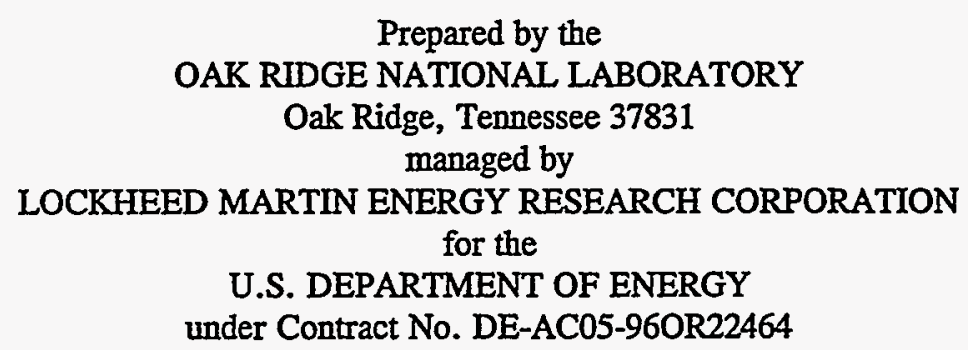




\section{DISCLAIMER}

Portions of this document may be illegible in electronic image products. Images are produced from the best available original document. 


\section{TABLE OF CONTENTS}

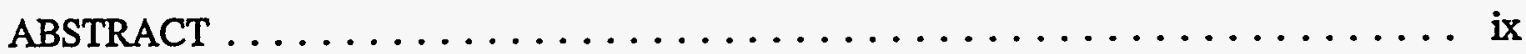

TABLE OF CONTENTS $\ldots \ldots \ldots \ldots \ldots \ldots \ldots \ldots \ldots \ldots \ldots \ldots \ldots \ldots$ iii

LIST OF TABLES AND FIGURES $\ldots \ldots \ldots \ldots \ldots \ldots \ldots \ldots \ldots \ldots, \ldots$

LIST OF ABBREVIATIONS, ACRONYMS, AND UNITS $\ldots \ldots \ldots \ldots \ldots \ldots$ vii

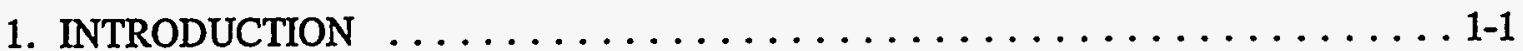

2. FACILITY DESCRIPTION AND OPERATIONS $\ldots \ldots \ldots \ldots \ldots \ldots \ldots \ldots 2-1$

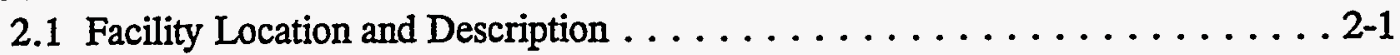

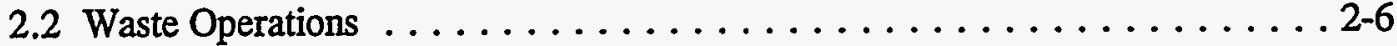

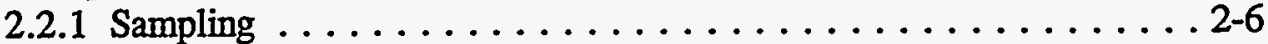

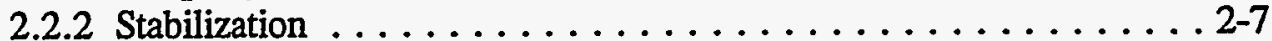

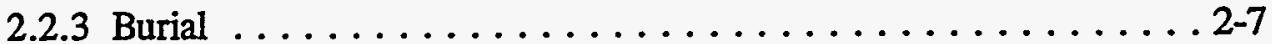

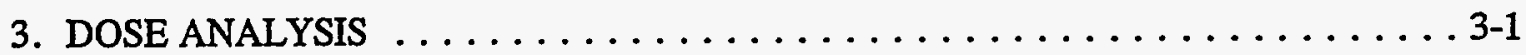

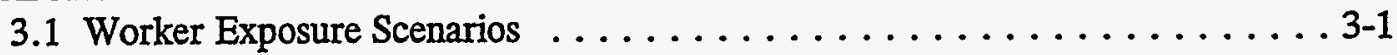

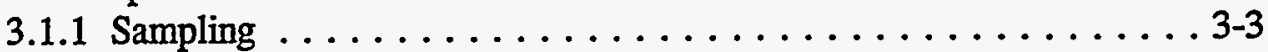

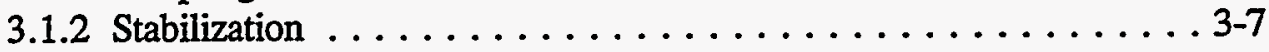

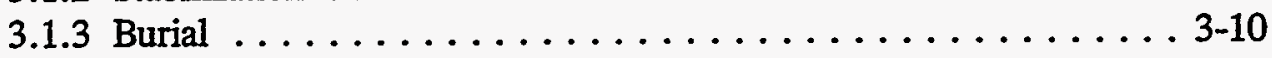

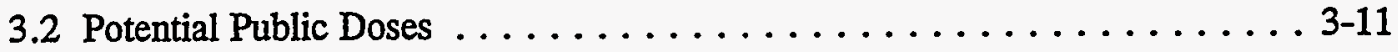

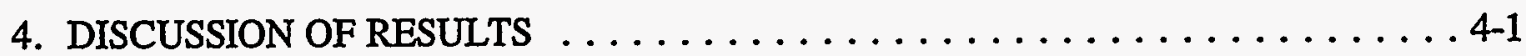

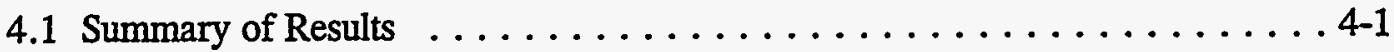

4.2 Comparison to Background and Regulatory Limits . . . . . . . . 4-1

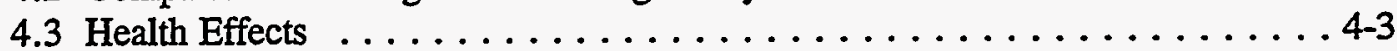

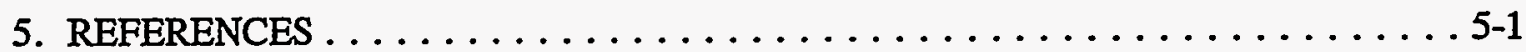

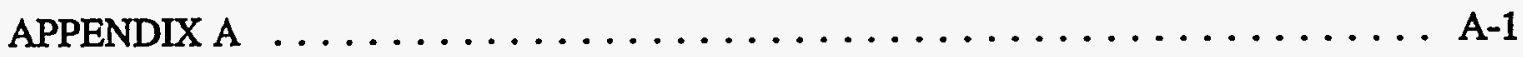




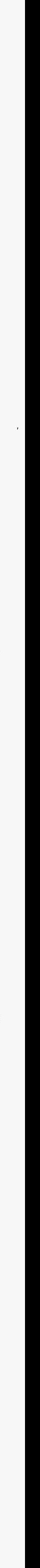




\section{LIST OF TABLES}

4.1 Summary of radiological doses $\ldots \ldots \ldots \ldots \ldots \ldots \ldots \ldots \ldots \ldots \ldots, 4$

\section{LIST OF FIGURES}

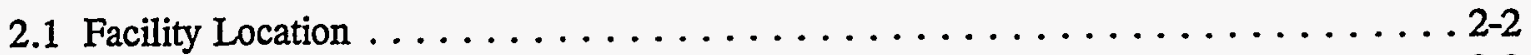

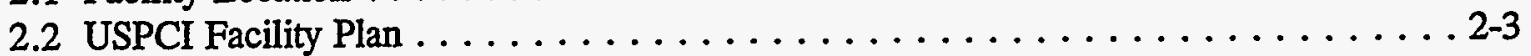

2.3 USPCI Liner and Leachate Collection System $\ldots \ldots \ldots \ldots \ldots \ldots \ldots \ldots \ldots \ldots \ldots \ldots \ldots \ldots$

3.1 Public Dose from Inhalation of Tritium $\ldots \ldots \ldots \ldots \ldots \ldots \ldots \ldots \ldots \ldots \ldots \ldots$ 



\section{LIST OF ABBREVIATIONS, ACRONYMS, AND UNITS}

ABBREVIATIONS AND ACRONYMS:

DCF dose conversion factor

DOE U.S. Department of Energy

EPA U.S. Environmental Protection Agency

HDPE high-density polyethylene

ICRP International Commission on Radiological Protection

NESHAP National Emissions Standards for Hazardous Air Pollutants

NRC U.S. Nuclear Regulatory Commission

RCRA Resource Conservation and Recovery Act

RESRAD RESRAD computer code, Version 5.60

USPCI U.S. Pollution Control, Inc.

\section{UNITS:}

$\begin{array}{ll}\mathrm{Bq} & \text { becquerel } \\ { }^{\circ} \mathrm{C} & \text { degrees Celsius } \\ \mathrm{Ci} & \text { curie } \\ \mathrm{cm} & \text { centimeter } \\ \mathrm{ft} & \text { foot/feet } \\ { }^{\mathrm{O}} \mathrm{F} & \text { degrees Fahrenheit } \\ \mathrm{g} & \text { gram } \\ \mathrm{in} & \text { inches } \\ \mathrm{K} & \text { kelvin } \\ \mathrm{km} & \text { kilometer } \\ \mathrm{m} & \text { meter } \\ \mathrm{ml} & \text { milliliter } \\ \mathrm{mm} \mathrm{Hg} & \text { millimeters of mercury } \\ \mathrm{mol} & \text { mole } \\ \mathrm{mrem} & \text { millirem } \\ \mathrm{mSv} & \text { milliSievert } \\ \mathrm{ppm} & \text { part per million } \\ \mathrm{s} & \text { second } \\ \mathrm{y} & \text { year } \\ \mathrm{yd} & \text { yard }\end{array}$





\begin{abstract}
The U.S. Department of Energy (DOE) Pinellas Plant in Largo, Florida is proposing to ship hazardous sludge, listed as F006 waste, to the U.S. Pollution Control, Inc. (USPCI) hazardous waste landfill in Tooele County, Utah for disposal. This sludge contains radioactive tritium in concentrations of about $28 \mathrm{pCi} / \mathrm{g}$. The objective of this study is to assess the possible radiological impact to workers at the USPCI facility and members of the public due to the - handling, processing, and burial of the DOE waste containing tritium. Listed below are the estimated doses to workers from waste handling activities and to the pubic from disposed waste. The doses are compared to natural background and applicable regulatory limits. The results of this highly conservative dose assessment reveal extremely low annual doses that are far below natural background radiation exposure and regulatory limits. Note that the estimated doses are incremental doses above background or other sources of radiation exposures.

Summary of radiological doses

\begin{tabular}{|c|c|c|c|}
\hline Exposure scenario & Dose $(\mathrm{mrem} / \mathrm{y})^{a}$ & $\begin{array}{l}\text { Fraction of natural } \\
\text { background }^{b}\end{array}$ & $\begin{array}{c}\text { Fraction of regulatory } \\
\text { limit }^{6}\end{array}$ \\
\hline Waste sampling & $4.7 \times 10^{-6}$ & $1.6 \times 10^{-8}$ & $9.4 \times 10^{-10}$ \\
\hline Waste stabilization & $6.0 \times 10^{-6}$ & $2.0 \times 10^{-8}$ & $1.2 \times 10^{-9}$ \\
\hline Waste burial & $9.8 \times 10^{-4}$ & $3.3 \times 10^{-6}$ & $2.0 \times 10^{-7}$ \\
\hline Public exposure $^{d}$ & $1.2 \times 10^{-5}$ & $4.0 \times 10^{-8}$ & $1.2 \times 10^{-6}$ \\
\hline \multicolumn{4}{|c|}{$\begin{array}{l}{ }^{a} \text { Waste sampling and waste stabilization are from short-term exposure scenarios that occur within one } \\
\text { year. Because the doses are so low, no acute radiation effects are anticipated. Therefore, the most reasonable } \\
\text { comparison is to annual background and annual occupational dose levels. The waste burial and public exposure } \\
\text { scenarios are from longer-term exposures that are also compared to annual background and annual occupational } \\
\text { doses. }\end{array}$} \\
\hline
\end{tabular}
\end{abstract}





\section{INTRODUCTION}

The U.S. Department of Energy (DOE) Pinellas Plant in Largo, Florida (Pinellas) is proposing to ship hazardous sludge to the U.S. Pollution Control, Inc. (USPCD) hazardous waste landfill in Tooele County, Utah for disposal. This sludge, listed under the Resource Conservation and Recovery Act (RCRA) regulations as F006 waste, contains radioactive tritium. RCRA F006 waste is defined as wastewater treatment sludges from electroplating operations [40 Code of Federal Regulations Part 261.30]. Because the waste contains tritium, DOE requires the preparation of a radiological dose assessment prior to shipment and disposal to ensure the protection of workers and the public from radiation hazards. A radiological dose assessment is necessary to meet the requirements of DOE to allow for an exemption from the department's moratorium on the off-site shipment of radioactively contaminated wastes. This assessment is modeled after a similar one conducted for Pinellas sludge that was sent to the a facility in South Carolina in 1992 (M. H. Chew \& Associates 1994).

The objective of this study is to assess an upper-bound radiological impact to workers at the USPCI facility and members of the public due to the handling, processing, and burial of the DOE waste containing tritium. Beta radiation (i.e., electrons resulting from the conversion of a neutron to a proton in the nucleus of an atom) from the tritium could result in radiation exposure to workers or members of the public. The potential off-site public dose is calculated as an upper bound for the hypothetical maximally exposed off-site individual. The study also compares the calculated doses with background radiation levels and applicable federal regulatory limits. Finally, associated health effects are discussed.

The remainder of this report is organized into three sections: (1) a description of the disposal facility and operations; (2) the dose analysis, including the methodology for calculating doses to workers and the public; and (3) a discussion of the results. 


\section{FACILITY DESCRIPTION AND OPERATIONS}

\subsection{Facility Location and Description}

The USPCI landfill facility is located in Tooele County, Utah. Tooele County is a rural area with a 1987 population of approximately 28,600 persons, located approximately 80 $\mathrm{km}(50 \mathrm{mi})$ west of Salt Lake City (NRC 1993). The closest population center to the landfill facility is the town of Wendover, on the Utah/Nevada border. Wendover is approximately 64 $\mathrm{km}(40 \mathrm{mi})$ west of the facility and has an approximate population of 1,100 persons (1990 census) (Fig. 2.1). The Tooele Army Depot is located approximately $80 \mathrm{~km}$ (50 mi) to the southeast. Tooele County encompasses over $1.8 \times 10^{6}$ ha $\left(4.4 \times 10^{6}\right.$ acres) of land. The federal government owns and controls $82 \%$ of the county, the State of Utah administers $6 \%$, and approximately $12 \%$ is privately owned. In 1988, the Tooele County Commission established the West Desert Hazardous Industry Area, which incorporates the USPCI landfill site. This designation limits the future uses of land in the vicinity of the site by prohibiting residential housing. The climate is arid with an average rainfall of approximately $13 \mathrm{~cm}(5 \mathrm{in}$.) per year (NRC 1993).

USPCI operates the Grassy Mountain Treatment, Storage and Disposal Facility. This facility contains six RCRA disposal landfill cells. Figure 2.2 shows the facility plan of the USPCI landfill. The Pinellas waste would most likely be disposed of in RCRA Cell 5, with the possibility of using RCRA Cell 4 . No other cells are currently available. The size of RCRA Cells 4 and 5, without a cover, are listed below:

- $\quad$ RCRA Cell $4-144 \mathrm{~m} \times 362 \mathrm{~m} \times 5.5 \mathrm{~m}=286,000 \mathrm{~m}^{3}(157 \mathrm{yd} \times 396 \mathrm{yd} \times 6 \mathrm{yd}=$ $376,000 \mathrm{yd}^{3}$ )

- $\quad$ RCRA Cell $5-114 \mathrm{~m} \times 109 \mathrm{~m} \times 22 \mathrm{~m}=273,000 \mathrm{~m}^{3}(125 \mathrm{yd} \times 119 \mathrm{yd} \times 24 \mathrm{yd}=$ $\left.363,000 \mathrm{yd}^{3}\right)$

The RCRA cells consist of a 0.9-m (3-ft) compacted clay liner with a permeability of less than $10^{-7} \mathrm{~cm} / \mathrm{sec}$, a secondary 60 mil high-density polyethylene (HDPE) liner, a secondary leachate detection/collection system, a primary 60 mil HDPE liner, a primary leachate/ collection system, a non-woven geotextile fabric, a $0.6-\mathrm{m}$ (2-ft) soil protective cover, a tertiary 80 mil HDPE liner, a tertiary leachate detection/collection system, a non-woven geotextile fabric, and a $0.6-\mathrm{m}(2-\mathrm{ft}$ ) protective soil layer (Fig. 2.3). Leachate is removed via a detection and collection system that drains into sumps. The leachate is transported off-site for treatment. 


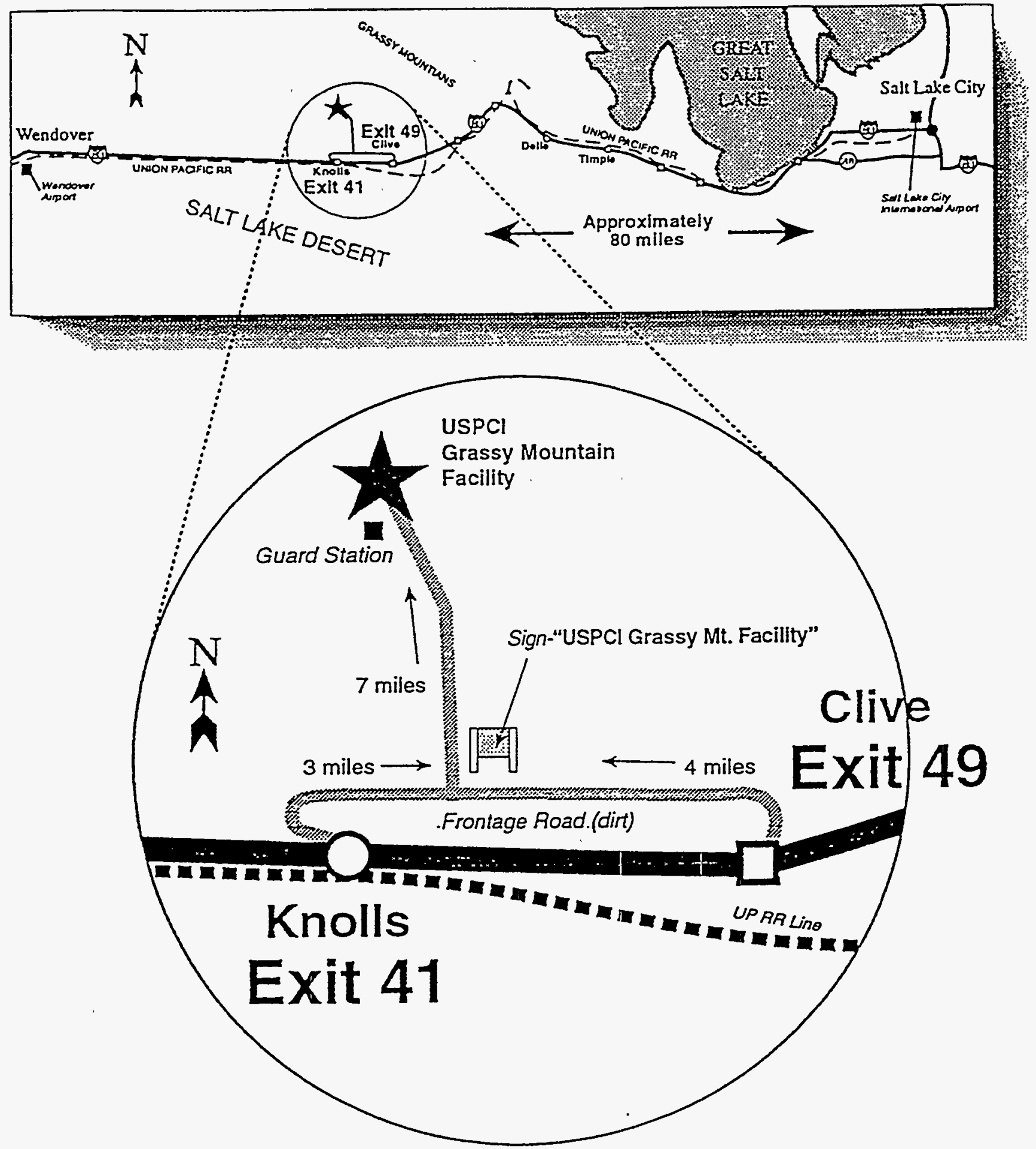

Fig. 2.1. Facility Location. 


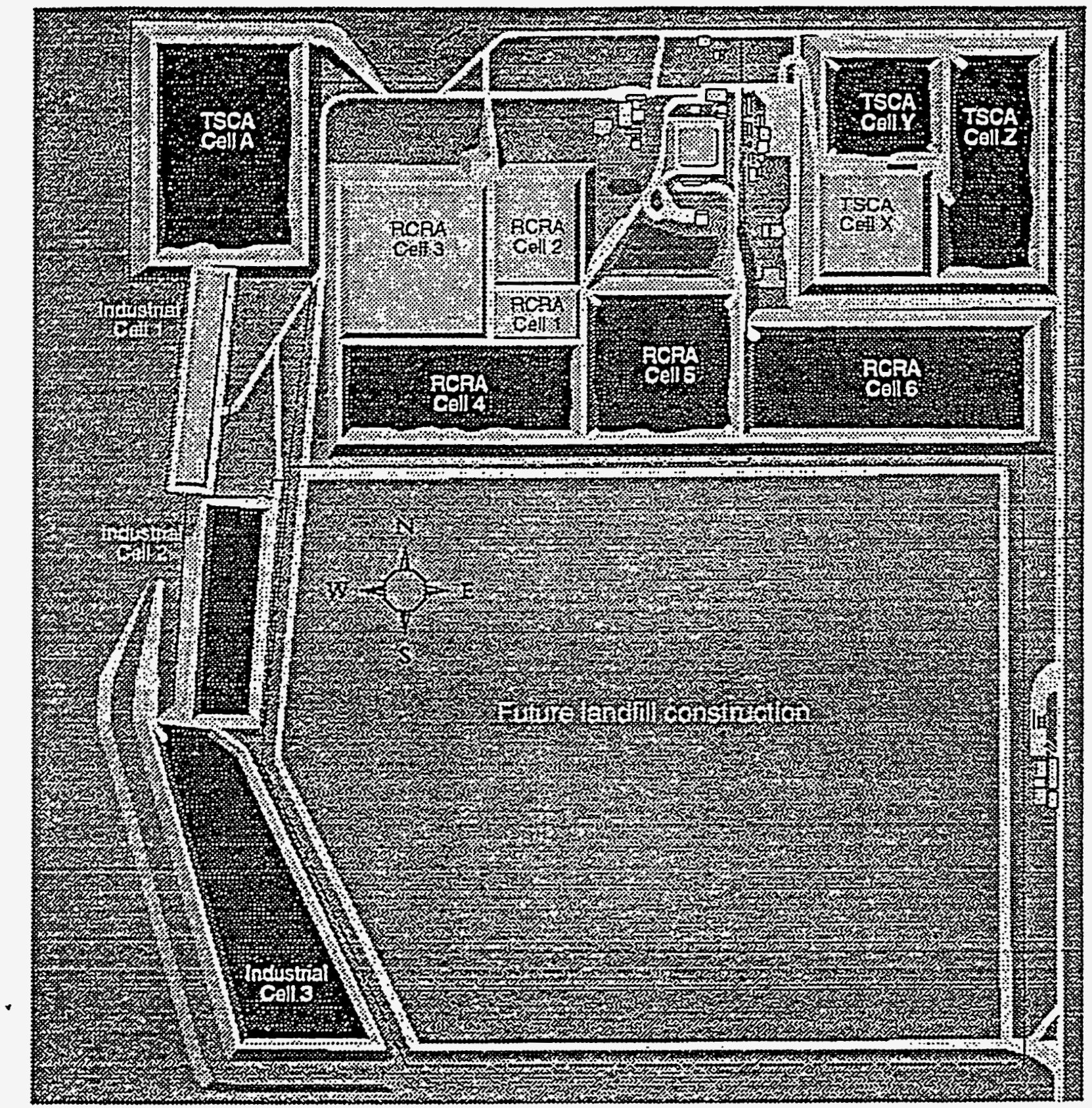

Fig. 2.2. USPCI Facility Plan. 


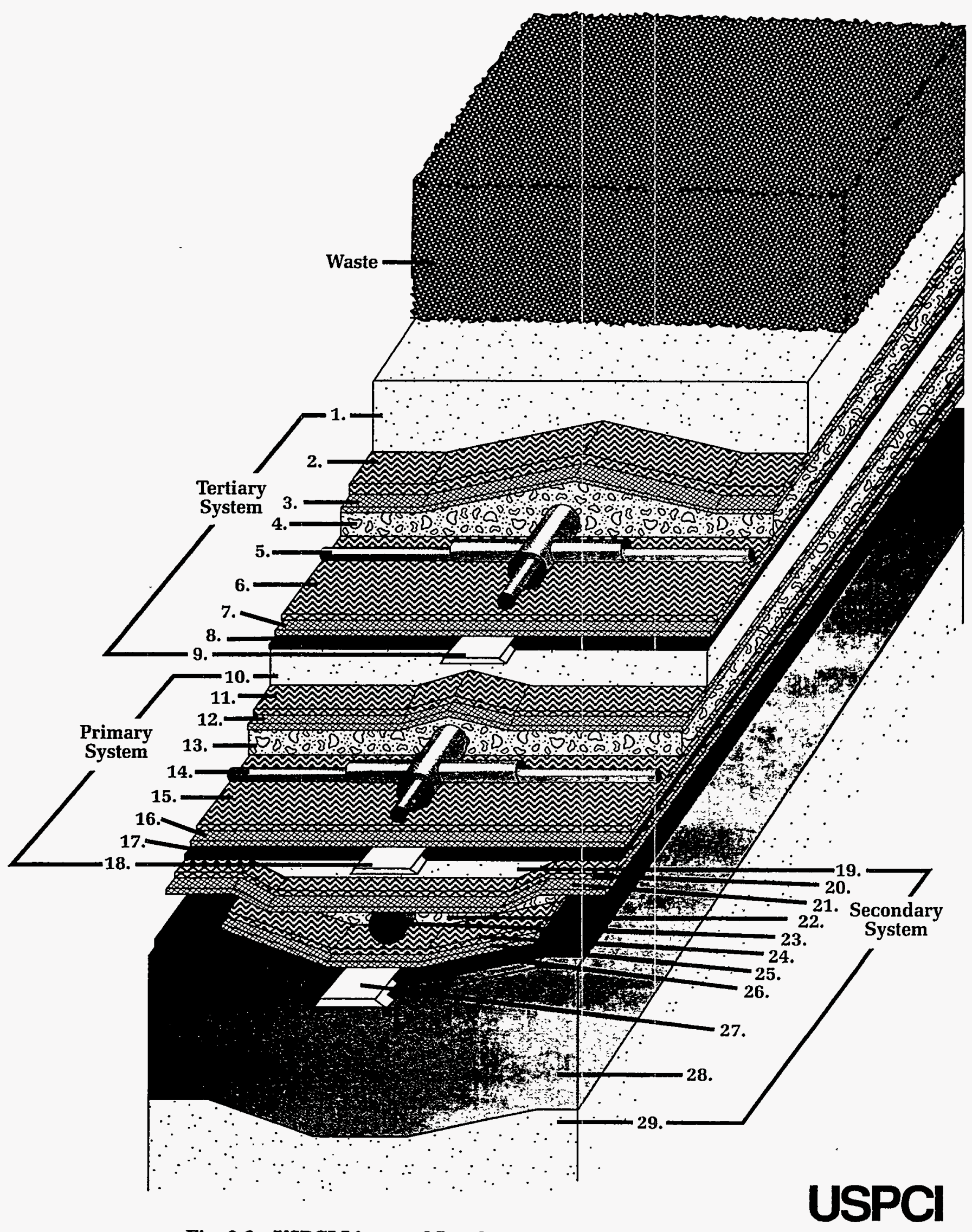

Fig. 2.3. USPCI Liner and Leachate Collection System. 
USPCI Liner and Leachate Collection System

\section{COMPONENT}

\section{Tertiary System}

1. Protective soil cover

2. Non-woven geotextile filter fabric

3. High Density Polyethylene (HDPE) drainage net

4. Rounded $3 / 4$ " washed rock

5. Sump \& piping system

6. Non-woven geotextile filter fabric

7. High Density Polyethylene (HDPE) drainage net

8. 80 mil HDPE liner

9. HDPE sump plates

\section{Primary System}

10. Protective soil cover

11. Non-woven geotextile filter fabric

12. High Density Polyethylene (HDPE) drainage net

13. Rounded 3/4" washed rock

14. Sump \& piping system

15. Non-woven geotextile filter fabric

16. High Density Polyethylene (HDPE) drainage net

17. 60 mil HDPE liner

18. HDPE sump plates

\section{Secondary System}

19. Protective soil cover

20. Non-woven geotextile filter fabric

21. High Density Polyethylene (HDPE) drainage net

22. Rounded 3/4" washed rock

23. Sump \& piping system

24. Non-woven geotextile filter fabric

25. High Density Polyethylene (HDPE) drainage net

26. 60 mil HDPE liner

27. HDPE sump plates

28. Compacted clay liner

29. Compacted soil base

\section{FUNCTION}

Protects liner from physical damage

Protects drainage net from clogging

Leachate collection

Leachate collection

Leachate collection

Protects drainage net from clogging

Leachate collection

Impermeable barrier/synthetic liner

Supports sump \& piping system/protects liner

Protects liner from physical damage

Protects drainage net from clogging

Leachate collection/leak detection

Leachate collection/leak detection

Leachate collection/leak detection

Protects drainage net from clogging

Leachate collection

Impermeable barrier/synthetic liner

Supports sump \& piping system/protects liner

Bedding for primary sump plate

Protects drainage net from clogging

Leachate collection/leak detection

Leachate collection/leak detection

Leachate collection/leak detection

Protects drainage net from clogging

Leachate collection/leak detection

Impermeable barrier/synthetic liner

Supports sump \& piping system/protects liner

Low permeability barrier

Foundation/dikes

Note: The sump consists of rounded aggregate wrapped in non-woven geotextile filter fabric and a second layer of HighDensity Polyethylene (HDPE) beneath the aggregate which acts as a protective rub sheet.

Fig. 2.3. (cont). 
The facility employs approximately 121 employees on site; approximately 38 are operational workers. At the landfill itself, there are five workers who might be present during waste handling and one supervisor who would be present approximately $20 \%$ of the time.

\subsection{Waste Operations}

Operations at the USPCI facility involved in handling the Pinellas waste include waste sampling, waste stabilization, and waste burial. Each is described below. If approved by the State of Utah, the transfer of Pinellas sludge to USPCI is expected to be conducted in October, 1995. The sludge would be transported in 5 vacuum boxes, each containing approximately $11.5 \mathrm{~m}^{3}\left(15 \mathrm{yd}^{3}\right)$ of sludge. The vacuum boxes have a capacity of $15 \mathrm{~m}^{3}\left(20 \mathrm{yd}^{3}\right)$, leaving $3.8 \mathrm{~m}^{3}\left(5 \mathrm{yd}^{3}\right)$ of headspace. The vacuum boxes are equipped with $61-\mathrm{cm}(24-\mathrm{in}$.) fill hatches and $10-\mathrm{cm}(4-\mathrm{in}$.$) flange drains.$

\subsubsection{Sampling}

A technician would take one representative sample [approximately $470 \mathrm{ml}$ (1 pint) or less] of Pinellas sludge from each of the 5 vacuum boxes. Sampling would be performed through the top fill hatches while the technician is standing on a platform immediately above the vacuum box. The worker would take a probable maximum of 15 minutes to sample any individual truck. Sampling would be conducted during the daytime at ambient temperatures, outside of any walls.

Samplers generally do not come into direct contact with the waste; samplers wear coated tyvek coveralls, hard hats, safety glasses with side shields, steel-toed boots, and latex gloves. They also wear cartridge-type full-face respirators while actually sampling from the truck, if any liquids are present; otherwise, a half-face respirator is used with safety glasses. The cartridges are combined particulate matter/organic vapor cartridges that also control acid gases, pesticides, mists and fumes, and radioactive particles. The cartridges used with the respirators do not filter tritium, therefore, no credit is given to the use of respirators in the dose analysis. Generally there are two samplers on duty at any given time, but each sampler obtains samples from a given truck independently.

Sampling consists of a series of relatively quick physical tests (e.g., color, appearance, $\mathrm{pH}$, reactivity to acid, etc.) to verify that the material exhibits the same gross physical characteristics that are described in the profile. All analyses are performed at the Grassy Mountain Laboratory, which is certified by the State of Utah. Analyses are performed in a lab 
room with controlled ventilation; testing which might evolve fumes is performed under a hood that exhausts directly to the outside air. Samples are bulked together for disposal, based on waste type or codes.

\subsubsection{Stabilization}

After a waste shipment is cleared from sampling, it is scheduled into stabilization. At the stabilization unit, the waste is drained into one of three open-topped, double-walled steel tanks. The tanks measure $6.1 \mathrm{~m} \mathrm{x} 6.1 \mathrm{~m}(20 \mathrm{ft} \times 20 \mathrm{ft}$ ) and have a working depth of $1.8 \mathrm{~m}$ ( $6 \mathrm{ft}$ ) (an approximate capacity of $67 \mathrm{~m}^{3}$, or 18,000 gallons). The sludge from two vacuum boxes are likely to be combined into the stabilization tank. Stabilizing agents (e.g., cement kiln dust, lime kiln dust, and portland cement) are added to bind the metals and free water. The waste and reagents are then mixed with a trackhoe bucket, which then transfers the mixture (now completely free of liquids) into end-dump trucks for transport to the landfill cell. As a result of adding the reagents, the volume of material ultimately placed in the cell is roughly 2.5 times that of the incoming waste. Before being removed from the tanks, the waste is sampled and tested to verify that no free liquids are present. For this analysis, the tritium is assumed to behave as normal hydrogen in the water molecule, and bind into the water/reagent matrix.

The entire time to stabilize a batch of waste varies, but each batch of this material should be stabilized and off-loaded into the disposal cell within 30 minutes. All stabilization is performed out-of-doors, at ambient temperatures. The reagents used react with water in a generally exothermic reaction, which may generate some water vapor.

All personnel on the stabilization unit will wear the same personal protective equipment as that described for the samplers, with the exceptions that they will also wear chemical resistant rubber boots and work gloves over the latex gloves and half-face respirators.

\subsubsection{Burial}

At the landfill cell, trucks dump the stabilized waste into a pile. The pile is pushed by a bulldozer into the final disposal area being used that day. All stabilized materials, once they are actually disposed of, are of a soil- or rock-like consistency. Less than 15 minutes generally is required to transport a batch of stabilized waste from the stabilization unit to the landfill cell. Although placement of the waste in the cell takes only minutes, workers are present in the cell and would be in the vicinity of the waste for approximately eight to nine hours of a ten-hour 
shift. Workers at the cells wear the same personal protective equipment as those at the stabilization unit.

The volume of the Pinellas waste that would be disposed of in either landfill cell is only a small fraction of the capacity of the cells. The volume of the Pinellas waste is determined from the volume of the incoming sludge. Five vacuum boxes, each containing approximately $11.5 \mathrm{~m}^{3}$ of sludge (Sect. 2.2), equals a total sludge volume of Pinellas waste of about $57.5 \mathrm{~m}^{3}$. With the addition of solidification materials during stabilization, the volume of the waste is increased by 2.5 times that of the incoming waste (Sect. 2.2.2). Therefore, the total volume of the waste is approximately $143 \mathrm{~m}^{3}$. The Pinellas waste would only constitute about $0.05 \%$ of the total volume capacity of either RCRA Cell 4 or 5 (i.e., $286,000 \mathrm{~m}^{3}$ and $273,000 \mathrm{~m}^{3}$, respectively) (Sect. 2.1). When the waste is placed in the landfill, the expected surface area dimensions of the waste are $6.7 \mathrm{~m}(22 \mathrm{ft}) \times 3.7 \mathrm{~m}(12 \mathrm{ft})=25.5 \mathrm{~m}^{2}\left(264 \mathrm{ft}^{2}\right)$ [L. Griffith, USPCI, Inc., personal communication with M. L. Socolof, Oak Ridge National Laboratory (ORNL), September 19, 1995]. The resulting depth of the waste placed in the landfill, based on a volume of $143 \mathrm{~m}^{3}$, is $5.8 \mathrm{~m}$.

There is no routine daily cover placed on the landfill cell, but when needed, water is sprayed on the cell surface to control dust. If there is a specific need, a cover can be applied over a given load or loads, using either clean soils from the surrounding area, or other heavier waste materials. Once a cell is completely full, it is covered by a minimum of the following: $0.6 \mathrm{~m}$ ( $2 \mathrm{ft}$ ) of recompacted clay, an 80-mil High Density Polyethylene Membrane Liner, a

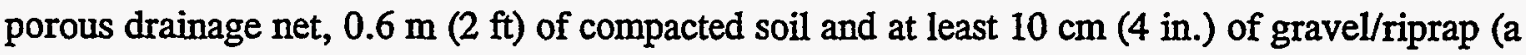
total of approximately $1.3 \mathrm{~m}$ or $4.3 \mathrm{ft}$ ). Up to $3 \mathrm{~m}$ (10 ft) of additional waste could also be placed over the Pinellas waste, before the cap is added. While the waste is sometimes covered the same day, the average time before the waste is covered is two weeks (L. Griffith, USPCI, Inc., personal communication with M. L. Socolof, ORNL, September 19, 1995). 


\section{DOSE ANALYSIS}

Tritium has a radiological half-life of 12.3 years and is a naturally occurring isotope of hydrogen produced by the interaction of cosmic ray protons and neutrons with nitrogen and oxygen atoms. Tritium is also a fission product of nuclear reactors as a result of neutron interaction with coolant additives and other reactor components. Tritium decays to helium-3 by emitting a low-energy beta particle $\left(\mathrm{E}_{\max }=0.0186 \mathrm{MeV}\right)$, precluding tritium from posing an external radiation hazard. However, tritium can pose an internal radiological hazard from inhalation, absorption, or ingestion. Tritium has essentially the same chemical behavior as stable isotopes of hydrogen (i.e., $\mathrm{H}-1$ and $\mathrm{H}-2$ ). This analysis assumes tritium acts as normal hydrogen in the water molecule. The following sections present the dose analyses for worker and public exposures to tritium in the Pinellas F006 sludge. All doses presented are effective dose equivalents ${ }^{1}$. The following dose analysis is based on a representative composite sample of the Pinellas F006 sludge that has a tritium concentration equal to $28.3( \pm 1.4) \mathrm{pCi} / \mathrm{g}$ and that consists of $91 \%$ unbound water (i.e., water that may transport out of the sludge matrix freely). Many assumptions are made throughout this analysis. Those that are referred to as conservative would result in a dose that is either a reasonable upper bound estimate or is higher than expected.

\subsection{Worker Exposure Scenarios}

The radioactive tritium contained in the DOE waste could be released to the atmosphere during (1) sampling and inspection of the waste, (2) stabilizing the waste, and (3) disposing of the waste in the landfill. For the first two operations, the internal dose from inhalation and skin absorption of tritiated water vapor (water vapor where one or both of the hydrogen atoms are replaced by tritium) is calculated assuming the sludge water evaporates into the worker's breathing zone. The models used simulate evaporation from a water spill, and therefore, the tritium activity concentration, by directly estimating the concentrations of water vapor in air (M.H. Chew \& Associates, Inc. 1994). The calculation of the dose to the burial worker is conducted using the computer code RESRAD, Version 5.60 (Yu et al. 1993), which estimates the doses over time from residual radioactivity in the landfilled waste. RESRAD uses a model that estimates evapotranspiration of tritium-laden water, while accounting for leaching and radioactive decay (described in Sect. 3.1.3). RESRAD was chosen over the water spill model because (1) the free water in the sludge is removed during the stabilization process, (2) the

\footnotetext{
${ }^{1}$ The effective dose equivalent is the weighted sum of the organ-specific doses given in millirem (mrem); 1 mrem equals 0.01 milliSievert (mSv).
} 
waste is landfilled and therefore affected by other natural phenomena (e.g., leaching), and (3) the exposure period extends beyond an acute exposure time.

Annual doses resulting from the sampling and stabilization scenarios are calculated using Eq. 3-1. Note that waste sampling and waste stabilization dose scenarios are from shortterm exposure scenarios that occur within one year. Therefore, the total dose from each scenario is represented as an annual dose. This is done so that the doses can be compared to annual background levels and annual regulatory limits. Since acute radiation poisoning is of no concern at the dose levels in this analysis, these "acute" exposure scenario doses will be compared to low-level chronic limits. The waste burial and public exposure scenarios are from longer-term exposures that are also presented as annual doses.

$$
H=C_{a} \times I R_{a} \times T \times N \times D C F
$$

where,

$$
\begin{aligned}
& H=\text { annual dose (rem/y), } \\
& C_{a}=\text { activity concentration of tritium in the air }\left(\mathrm{Ci} / \mathrm{m}^{3}\right), \\
& \left.I R_{a}=\text { inhalation rate of air (worker, light exercise: } 4.2 \times 10^{-4} \mathrm{~m}^{3} / \mathrm{s}\right)(\mathrm{ICRP} 1994), \\
& T=\text { exposure time of each operation (s), } \\
& N=\text { number of operations }\left(5 \mathrm{y}^{-1}\right), \text { and } \\
& D C F=\text { inhalation/percutaneous dose conversion factor for tritium }(96 \mathrm{rem} / \mathrm{Ci})(\mathrm{EPA} \\
& \quad \text { 1988; ICRP 1979). }
\end{aligned}
$$

The values of $C_{a}$ and $T$ will vary for each occupational activity. Descriptions and calculations of the scenario-specific components are presented in Sects. 3.1.1 and 3.1.2. The inhalation rate of a worker during light exercise of $4.2 \times 10^{-4} \mathrm{~m}^{3} / \mathrm{s}$ (ICRP 1994) is used in the occupational exposure scenarios. The number of operations, which would occur during one year, is 5 . The dose conversion factor (DCF) for tritium in the U. S. Environmental Protection Agency's (EPA's) Federal Guidance Report No. 11 (EPA 1988) is $1.73 \times 10^{-11} \mathrm{~Sv} / \mathrm{Bq}$ (64 rem/Ci). This DCF does not include the dose contribution from absorption of tritiated water vapor through the skin, which amounts to about 50\% of the inhalation dose (ICRP 1979). Therefore, the EPA $\mathrm{DCF}$ is increased by $50 \%$ to equal $96 \mathrm{rem} / \mathrm{Ci}$ in this analysis. 


\subsubsection{Sampling}

This section uses a water evaporation model to estimate the internal dose to workers from inhalation and absorption of the tritium released to the atmosphere during inspection and sampling of the vacuum boxes containing contaminated sludge. The atmospheric concentration $\left(C_{a}\right)$ in Eq. 3-1 is calculated from the initial concentration of tritium in the vacuum box, the release of tritium out of the vacuum box into the atmosphere, and the dilution of tritium in the atmosphere once released. Due to evaporation, tritiated water vapor fills the vacuum box headspace. First the water vapor concentration in the vacuum box headspace $\left(C_{w v, h s}\right)$ is calculated assuming evaporation from a water spill (M. H. Chew \& Associates 1994):

$$
C_{w v, h s}=\left(\frac{M W}{V_{0}}\right)\left(\frac{P_{v a p}}{P_{0}}\right)\left(\frac{T_{0}}{T_{v a p}}\right)
$$

where,

$C_{w, h s}=$ concentration of water vapor in the vacuum box headspace $\left(\mathrm{g} / \mathrm{m}^{3}\right)$,

$M W=$ molecular weight of water $(18 \mathrm{~g} / \mathrm{mol})$,

$V_{0}=$ volume of 1 mole of gas at standard conditions $\left(0.0224 \mathrm{~m}^{3} / \mathrm{mol}\right)$,

$P_{\text {vap }}=$ saturation water vapor pressure at $25^{\circ} \mathrm{C}(24 \mathrm{~mm} \mathrm{Hg})$,

$P_{0}=$ standard pressure $(760 \mathrm{~mm} \mathrm{Hg})$,

$T_{0}=$ standard temperature $(273 \mathrm{~K})$, and

$T_{\text {vap }}=$ vapor temperature $(\mathrm{K})\left(25^{\circ} \mathrm{C}=298 \mathrm{~K}\right)$.

This analysis conservatively assumes that all the water vapor in the headspace comes from the waste and that all the tritium is in the sludge water. The calculation requires the saturation water vapor pressure as input into the equation, which depends on temperature (i.e., the higher the temperature, the greater the vapor pressure of water). 'This analysis assumes the watervapor pressure is $24 \mathrm{~mm} \mathrm{Hg}$, corresponding to water at $25^{\circ} \mathrm{C}\left(78^{\circ} \mathrm{F}\right)$. This temperature is a conservative estimate for average temperatures in October in Tooele. The average daily temperature in Tooele in October is $11^{\circ} \mathrm{C}\left(52^{\circ} \mathrm{F}\right)$ (NRC 1993). Since operations are expected to occur during the daytime, the temperatures would be higher than this daily average. However, the normal daily maximum in Salt Lake City in October is $19^{\circ} \mathrm{C}\left(66^{\circ} \mathrm{F}\right)$ (DOC 1995), which is below the $25^{\circ} \mathrm{C}$ assumed in this analysis. This analysis is conservative since the higher the temperature, the greater evaporation and thus a greater air concentration of tritium. 
Substituting the above values into Eq. 3-2, the water vapor concentration $\left(C_{w v, h s}\right)$ is $23 \mathrm{~g} / \mathrm{m}^{3}$. The concentration of tritium in the vacuum box headspace depends on the amount of tritium in the sludge water and the amount of water vapor in the headspace. Assuming that tritium acts as water vapor, the initial concentration in the headspace is calculated as:

$$
C_{h s}{ }^{0}=\left(\frac{A}{f_{w a t}}\right) C_{w v, h s}
$$

where,

$$
\begin{aligned}
& C_{h s}^{0}=\text { initial activity concentration of tritium in the vacuum box headspace (before } \\
& \text { hatch is opened for sampling) }\left(\mathrm{Ci} / \mathrm{m}^{3}\right), \\
& A=\text { activity of tritium in sludge }\left(2.83 \times 10^{-11} \mathrm{Ci} / \mathrm{g}\right), \\
& f_{w a t}=\text { fraction of water in the sludge }(0.91) \text { (dimensionless), and } \\
& C_{w v, h s}=\text { mass concentration of water vapor in the vacuum box headspace }\left(\mathrm{g} / \mathrm{m}^{3}\right)
\end{aligned}
$$

(Eq. 3-2).

Initial sampling of the sludge revealed an average tritium activity $(A)$ of $2.83 \times 10^{-11}$ $\mathrm{Ci} / \mathrm{g}$ and the fraction of water in the sludge $\left(f_{\text {wat }}\right)$ of 0.91 . Substituting these values and the $C_{w v, h s}$ value from Eq. 3-2 into Eq. 3-3 yields a $C_{h s}{ }^{0}$ of $7.2 \times 10^{-10} \mathrm{Ci} / \mathrm{m}^{3}$. This equation assumes that the tritium is only in the water. Worker exposure occurs when the vacuum box is opened and tritium is released and diluted in the ambient air. The tritium exposure concentration in the air depends on the time-dependent tritium activity in the headspace and the dilution of the headspace volume once exposed to the atmosphere. The time-dependent tritium activity concentration in the headspace $\left[C_{h s}(t)\right]$ due to leakage can then be obtained by integrating the following mass balance equation (M.H. Chew \& Associates 1994):

$$
\frac{d C_{h s}(t)}{d t}=-\frac{F C_{h s}^{0}}{V_{h s}}
$$

which yields,

$$
C_{h s}(t)=C_{h s}{ }^{0} \exp \left(\frac{-F t}{V_{h s}}\right)
$$


where,

$C_{h s}(t)=$ tritium activity concentration in the headspace as a function of time $\left(\mathrm{Ci} / \mathrm{m}^{3}\right)$,

$C_{h s}{ }^{0}=$ initial tritium activity concentration in the vacuum box headspace $\left(\mathrm{Ci} / \mathrm{m}^{3}\right)$,

$F=$ leakage rate $\left(0.058 \mathrm{~m}^{3} / \mathrm{s}\right)$, and

$V_{h s}=$ volume of the vacuum box headspace $\left(3.8 \mathrm{~m}^{3}\right)$.

The leakage rate is scaled from a leakage rate for a $1.9-\mathrm{m}^{2}$ door in calm weather conditions of $0.38 \mathrm{~m}^{3} / \mathrm{s}$ (Strock and Koral 1965 in M.H. Chew \& Associates 1994). The leakage rate for a $0.61-\mathrm{m}(2-\mathrm{ft})$ circular hatch is $0.058 \mathrm{~m}^{3} / \mathrm{s}$. This would correspond to an exit velocity of 0.20 $\mathrm{m} / \mathrm{s}$ (calculated by dividing the leakage rate by the area of the hatch opening).

The vapor concentration outside the vacuum box is diluted by the air outside the box.

The dilution of the headspace volume, when exposed to the atmosphere, is calculated as follows:

$$
D I L=\frac{\left(V_{a}+V_{w}\right)}{V_{a}}
$$

where,

$$
\begin{aligned}
& V_{a}=v \times 1 \mathrm{sec} \times \pi(L / 2)^{2}, \\
& V_{w}=v \times 1 \mathrm{sec} \times u \times 1 \mathrm{sec} \times L,
\end{aligned}
$$

and

$$
\begin{aligned}
& D L=\text { dilution factor (dimensionless), } \\
& V_{a}=\text { volume of air that leaks through the opening in } 1 \mathrm{~s}\left(\mathrm{~m}^{3}\right), \\
& V_{w}=\text { dilution volume of air outside the opening due to wind dispersion in } 1 \mathrm{~s}\left(\mathrm{~m}^{3}\right), \\
& v=\text { exit velocity of tritiated air from vacuum box }(0.20 \mathrm{~m} / \mathrm{s}), \\
& u=\text { wind speed (conservatively assume calm conditions: } 0.5 \mathrm{~m} / \mathrm{s}), \text { and } \\
& L=\text { diameter of vacuum box opening }[0.61 \mathrm{~m}(2 \mathrm{ft})]
\end{aligned}
$$

In calculating $V_{w}$, a vertical mixing depth of the one-second travel distance of contaminated air moving at the exit velocity $(0.20 \mathrm{~m})$ is assumed (i.e., the product of $v \times 1 \mathrm{sec}$ ). This is the distance above the opening within which the tritiated water vapor is assumed to be mixed into the outside air passing over the opening. For times beyond 1 second, the velocity of the outside air would have moved the tritiated vapor beyond the breathing zone of the sampling worker. This is a conservative assumption since the individual taking the sample is not likely to get closer than $0.6 \mathrm{~m}$ ( $2 \mathrm{ft}$ ) from the opening. 
A calm wind speed $(u)$ of $0.5 \mathrm{~m} / \mathrm{s}$ is used. This is a conservative assumption since the wind speed would likely be higher [the annual average wind speed in Salt Lake City, Utah is approximately $4 \mathrm{~m} / \mathrm{s}$ (DOC 1995)] and because wind speed and concentration are inversely related (i.e., the lower the wind speed, the lower the dilution and consequently, the higher the concentration of tritium in the air). Using the given values of $v, u$, and $L$ in Eq. 3-6, the values of $V_{a}$ and $V_{w}$ equal $0.058 \mathrm{~m}^{3}$ and $0.060 \mathrm{~m}^{3}$, respectively. Subsequently, the dilution factor is 2.0 .

The concentration of tritium in the air is the concentration in the headspace divided by the dilution factor.

$$
C_{a}=\frac{C_{h s}(t)}{D I L}
$$

where,

$C_{a}=$ activity concentration of tritium in the air $\left(\mathrm{Ci} / \mathrm{m}^{3}\right)$,

$C_{h s}(t)=$ time-dependent activity concentration of tritium in the vacuum box headspace $\left(\mathrm{Ci} / \mathrm{m}^{3}\right)$, and

$D I L=$ dilution factor from surrounding outside air (2.0; Eq. 3-6).

The concentration in the outside air is then calculated by combining Eqs. 3-5 and 3-7,

$$
C_{a}=\frac{C_{h s}{ }^{0} \exp \left(\frac{-F t}{V_{h s}}\right)}{D I L} .
$$

This concentration is then used to calculate the dose to the sampler. Since the concentration in the air is a function of time, the dose is integrated over the sampling exposure time. This is shown below as the definite integral of Eq. 3-1 from time zero to time $T$.

$$
H=\int_{0}^{T} C_{a}(t) \times I R_{a} \times N \times D C F d t
$$

where,

$H=$ annual dose (rem/y),

$T=$ exposure time of each operation (900 s), 
$C_{a}(t)=$ activity concentration of tritium in the air as a function of time $\left(\mathrm{Ci} / \mathrm{m}^{3}\right)$, $I R_{a}=$ inhalation rate of air (worker, light exercise: $4.2 \times 10^{-4} \mathrm{~m}^{3} / \mathrm{s}$ ) (ICRP 1994),

$N=$ number of operations $\left(5 \mathrm{y}^{-1}\right)$, and

$D C F=$ inhalation/percutaneous dose conversion factor for tritium $(96 \mathrm{rem} / \mathrm{Ci})$ (EPA 1988; ICRP 1979).

The definite integral from time zero to time $T$ is expressed as

$$
H=\left(\frac{C_{h s}^{0}}{D I L}\right)\left(\frac{V_{h s}}{F}\right)\left[1-\exp \left(\frac{-F T}{V_{h s}}\right)\right] I R_{a} \times N \times D C F
$$

The sampling exposure scenario assumes one worker conducts all 5 sampling operations $(N=5)$ and each operation takes 15 minutes (900-s) exposure time. Substituting in each term given above into Eq. 3-10, and converting rem to mrem, the annual dose to one worker from sampling all the Pinellas waste is $1.2 \times 10^{-5} \mathrm{mrem} / \mathrm{y}$.

\subsubsection{Stabilization}

The Pinellas sludge will be placed into the open stabilization tank for treatment. Two loads of sludge likely would be stabilized together, however, for this analysis, each of the five loads are assumed to be stabilized separately. During stabilization, tritium may be released to the atmosphere as a result of evaporation of the water content in the sludge. The potential exposure would be from tritiated water vapor above the tank. The concentration of tritiated water vapor in the air above the tank $\left(C_{\partial}\right)$ is calculated by estimating the concentration of water vapor above the tank, for which the source term is the evaporation of water from the tank and the removal term is advection in the wind and ambient air. The mass balance equation for the concentration of water vapor above the tank, representing the time-dependent concentration in relation to the source term and the removal term is as follows:

$$
\frac{d C_{w v}}{d t}=\frac{A_{t} Q}{V}-\frac{u A_{s} C_{w v}}{V}
$$

where,

$$
\begin{aligned}
C_{w \nu}= & \text { mass concentration of water vapor in a volume of air above the stabilization tank } \\
& \left(\mathrm{g} / \mathrm{m}^{3}\right),
\end{aligned}
$$


$A_{t}=$ surface area of the top of the stabilization tank $\left(\mathrm{m}^{2}\right)\left(6.1 \mathrm{~m} \mathrm{x} 6.1 \mathrm{~m}=37 \mathrm{~m}^{2}\right)$, $Q=$ water evaporation rate per unit area $\left(\mathrm{g} / \mathrm{s}-\mathrm{m}^{2}\right)$,

$V=$ volume of waste in stabilization $\operatorname{tank}\left(\mathrm{m}^{3}\right)$,

$u=$ wind speed (assume calm winds, $0.5 \mathrm{~m} / \mathrm{s}$ ), and

$A_{s}=$ cross sectional area of a side of mixing volume above the mixing stabilization $\operatorname{tank}\left(\mathrm{m}^{2}\right)\left(6.1 \mathrm{~m} \mathrm{x} 0.77 \mathrm{~m}=4.7 \mathrm{~m}^{2}\right)$.

Assuming steady state conditions, the time-dependent term in Eq. 3-11 is set equal to zero.

This results in the following simplified equation:

$$
C_{w y}=\frac{A_{t} Q}{u A_{s}} .
$$

This analysis assumes a certain mixing volume above the stabilization tank, the dimensions of which are used to calculate the top and cross-sectional surface areas. The mixing volume is assumed to be equivalent to the volume of the waste in the tank. Therefore, using the dimensions of the stabilization tank $(6.1 \mathrm{~m} \times 6.1 \mathrm{~m} \mathrm{x} 1.8 \mathrm{~m})$, the surface area of the top of the tank $\left(A_{t}\right)$ equals $6.1 \mathrm{~m} \mathrm{x} 6.1 \mathrm{~m}$, or $37 \mathrm{~m}^{2}$. The height of the mixing zone above the tank is assumed to be the same as the depth of the grouted waste in the tank. The depth of the sludge is calculated from the original volume of one load of sludge (approximately $11 \mathrm{~m}^{3}$ ), which is increased by a factor of 2.5 by the addition of stabilization agents. The cross-sectional area $\left(A_{s}\right)$ is then calculated with the height and width of the waste $\left(6.1 \mathrm{~m} \times 0.77 \mathrm{~m}=4.7 \mathrm{~m}^{2}\right)$. A calm wind speed $(u)$ of $0.5 \mathrm{~m} / \mathrm{s}$ is used. The evaporation rate is conservatively estimated below based on a water spill (EPA 1987), which uses the ideal gas law and wind speed.

$$
\mathcal{Q}=\frac{M W K P_{v a p}}{R T_{v a p}}
$$

where,

$$
K=0.25 u^{0.78}
$$

and

$$
Q=\text { water evaporation rate per unit area }\left(\mathrm{g} / \mathrm{s}-\mathrm{cm}^{2}\right) \text {, }
$$


$M W=$ molecular weight of water $(18 \mathrm{~g} / \mathrm{mol})$,

$K=$ gas phase mass transfer coefficient $(\mathrm{cm} / \mathrm{s})$,

$P_{\text {vap }}=$ saturation vapor pressure $\left(24 \mathrm{~mm} \mathrm{Hg}\right.$ at $\left.25^{\circ} \mathrm{C}\right)$,

$R=$ gas constant $62,358 \mathrm{~mm} \mathrm{Hg}-\mathrm{cm}^{3} / \mathrm{mol}-\mathrm{K}$,

$T_{\text {vap }}=$ vapor temperature $(\mathrm{K})\left(25^{\circ} \mathrm{C}=298 \mathrm{~K}\right)$, and

$u=$ wind speed $(0.5 \mathrm{~m} / \mathrm{s})$.

Substituting the values given above into Eq. 3-13, the water evaporation rate per unit area $(Q)$ is $3.4 \times 10^{-6} \mathrm{~g} / \mathrm{s}-\mathrm{cm}^{2}$. To substitute $Q$ into Eq. 3-12, the value must be converted to $0.034 \mathrm{~g} / \mathrm{s}$ $\mathrm{cm}^{2}$ so that the units are consistent. Substituting $Q$ into Eq. 3-12 yields a water vapor concentration above the stabilization tank $\left(C_{w v}\right)$ of $0.54 \mathrm{~g} / \mathrm{m}^{3}$. Substituting that water vapor concentration value into the right hand side of Eq. 3-3 yields a tritium concentration in the air above the $\operatorname{tank}\left(C_{a}\right)$ for the stabilization scenario.

$$
C_{a}=\left(\frac{A}{f_{w a t}}\right) C_{w v}
$$

where,

$$
\begin{aligned}
C_{a}= & \text { activity concentration of tritium in a volume of air above the stabilization tank } \\
& \left(\mathrm{Ci} / \mathrm{m}^{3}\right), \\
A= & \text { activity of tritium in sludge }\left(2.83 \times 10^{-11} \mathrm{Ci} / \mathrm{g}\right), \\
f_{\text {war }}= & \text { fraction of water in the sludge }(0.91) \text { (dimensionless), and } \\
C_{w v}= & \text { mass concentration of water vapor in a volume of air above the stabilization } \\
& \text { tank }\left(\mathrm{g} / \mathrm{m}^{3}\right) .
\end{aligned}
$$

The concentration of tritium in the air, to which a worker is exposed, is calculated to be $1.7 \times 10^{-11} \mathrm{Ci} / \mathrm{m}^{3}$. This concentration is then substituted into Eq. 3-1 to calculate the dose. The exposure time is conservatively assumed to be $30 \mathrm{~min}(1800 \mathrm{~s})$ per vacuum box of sludge, which is the time for stabilization activities and transfer to the disposal cell. The same worker also is assumed to conduct all five stabilization operations $(N=5)$. The calculated dose from Eq. 3-1 for stabilization operations, after being converted from rem to mrem, is $6.0 \times 10^{-6}$ $\mathrm{mrem} / \mathrm{y}$. 


\subsubsection{Burial}

The RESRAD code (Yu et al. 1993) is used to calculate the inhalation dose to a landfill worker. The maximum potential exposure is estimated assuming tritium is released to the atmosphere from the grouted sludge. RESRAD uses a tritium model based on specific activity. The model is based on the fact that tritium has essentially the same chemical behavior as stable isotopes of hydrogen (i.e., $\mathrm{H}-1, \mathrm{H}-2$ ). Therefore, tritium occurs in the environment in concentrations that are proportional to the ratio of tritium to stable hydrogen in the environment (Yu et al. 1993). Furthermore, the circulation of tritium in the environment generally is expected to closely follow that of water. The RESRAD moclel assumes tritium acts as water and calculates the amount of tritium in the environment as water vapor from evaporation. The model also accounts for evapotranspiration, leaching, runoff, erosion, and radioactive decay.

To calculate the evaporation of tritium from the waste into the air, the dimensions of the waste are needed. These are assumed to be $6.7 \mathrm{~m} \mathrm{x} 3.7 \mathrm{~m} \mathrm{x} 5.8 \mathrm{~m}$ in the RCRA landfill cell (Sect. 2.2.3). Tritium is assumed to be released to the atmosphere from the grouted waste form. The worker is assumed to be exposed to the waste form before it is covered in the RCRA cell. The waste form dimensions are used to determine the concentration in the soil, which is then used to calculate a concentration in the air. RESRAD calculates an air concentration by accounting for the humidity in the air, the density of the waste and soil cover, the hydraulic conductivity of the waste, the erosion rate of the cover soil and the waste, the porosity of the waste, the precipitation rate, the irrigation rate, and evapotranspiration and runoff characteristics. All parameter values are presented in Appendix A, Sect. A.1.

The mean annual absolute humidity for Utah and surrounding states is $4.7 \mathrm{~g} / \mathrm{m}^{3}$ (Yu et al. 1993, p. 310). The density of the waste is assumed to be about $1.2 \mathrm{~g} / \mathrm{cm}^{3}$, and the hydraulic conductivity of the waste is assumed to be $10 \mathrm{~m} / \mathrm{y}$. These values are the same as those of similar Pinellas waste that underwent similar treatment that was sent to South Carolina for disposal in 1992 (M.H. Chew \& Associates 1994). The erosion rate of the contaminated zone (RESRAD default value of $0.001 \mathrm{~m} / \mathrm{y}$ ) is used and is insensitive to the calculated dose and, therefore, a more precise value is not needed for this analysis.

The porosity, precipitation rate, irrigation rate, evapotranspiration coefficient, and runoff coefficient are used to calculate the infiltration of water through the contaminated zone to estimate leaching. The effective porosity of the contaminated zone, on average, is estimated to be 0.3 (L. Griffith, USPCI, Inc., personal communication with M. L. Socolof, ORNL, September 7,1995$)$. The annual rainfall is approximately $0.13 \mathrm{~m}$. Although there is no irrigation in the area, the landfill cells are sometimes sprayed with water for dust suppression 
purposes. The introduction of irrigation or dust suppression water would increase leaching and thus decrease the atmospheric release of tritium from the waste. Therefore, assuming no "irrigation" term is conservative. The runoff coefficient assumes the land is flat, with open sandy loam and cultivated lands (as opposed to woodlands) (Yu et al. 1993, p. 199). The evapotranspiration coefficient, which can vary between 0 and 1 , conservatively is assumed to be at the upper bound of 1.0 .

A worker conservatively is assumed to be exposed to atmospheric releases from the waste nine hours a day for 250 work days in a year $\left(8.1 \times 10^{6} \mathrm{~s} / \mathrm{y}\right)$. The inhalation rate used assumes conditions of light exercise $\left(4.2 \times 10^{-4} \mathrm{~m}^{3} / \mathrm{s}\right.$ ) (ICRP 1994). The internal dose conversion factor of $96 \mathrm{rem} / \mathrm{Ci}$ for inhalation and absorption is also used (EPA 1988; ICRP 1979). The resulting annual dose is $9.8 \times 10^{-4}$ mrem. Appendix A lists the specific input parameters used by the RESRAD code to calculate the burial worker dose and presents the RESRAD output.

\subsection{Potential Public Doses}

The most likely radiation dose to the public from the disposal of Pinellas waste at the USPCI facility is based on atmospheric emission of tritium. Exposure via groundwater and surface water is not included because the assumption that USPCI releases lead to exposures through these pathways is not reasonable. The groundwater consists of a shallow salty-brine aquifer. Groundwater flow is slow [e.g., two test results of hydraulic conductivity are $5 \times 10^{-4}$ and $1.9 \times 10^{-4} \mathrm{~cm} / \mathrm{s}\left(9.93 \times 10^{-4}\right.$ and $\left.\left.3.78 \times 10^{-5} \mathrm{ft} / \mathrm{min}\right)\right]$ and the deeper zone of the aquifer has an upward gradient. The groundwater quality is poor (e.g., high average total dissolved solids level ranging from 88,000 to $100,000 \mathrm{ppm}$; high chloride level of about $44,000 \mathrm{ppm}$ ) (L. Griffith, USPCI, Inc., personal communication with M. L. Socolof, ORNL, September 7 and 19, 1995). The groundwater and surface waters in the area of the USPCI site do not have beneficial uses (e.g., potable water, fishing). The nearest pubic drinking water source is a groundwater source in the town of Gransville, approximately $97 \mathrm{~km}$ (60 mi) east-southeast of the site. Surface water is essentially absent from the area. Surface water quality data are generally unavailable for Tooele County, which is a reflection of the lack of water and population centers. The only water quality station is in Big Spring near Timpie [about $32 \mathrm{~km}$ $(20 \mathrm{mi})$ east of the site]. The spring feeds a waterfowl management area and has no other uses. The water is very hard and very high in dissolved solids, primarily sodium chloride. Moderate concentrations of arsenic, nickel, copper, and silver are also present (NRC 1993).

No food crops are grown or cattle grazed in this desert region. The only grazing that may occur is during the spring in the Grayback Mountains [never occurring closer than $8 \mathrm{~km}$ 
( $5 \mathrm{mi}$ ) to the landfill]. Therefore, the greatest potential for public exposure is through direct inhalation. The public dose is calculated using RESRAD (Yu et al. 1993), which assumes a hypothetical maximally exposed individual, located directly above the covered waste, is inhaling tritium released to the atmosphere.

Most of the same site-specific parameters used for the burial worker assessment are used to calculate the public dose. However, for the public exposure scenario, the waste is assumed to be covered and the maximally exposed member of the public is assumed to spend $100 \%$ of his time breathing contaminated air released from the landfill. This analysis conservatively assumes exposure begins immediately after the waste is put in place and covered. This assumption ignores (1) the required 30-year institutional control period stipulated in the facility's RCRA permit and (2) the fact that the facility will likely operate for an additional 30 to 50 years. Regarding the landfill cover, the RESRAD code uses a reference cover depth of $0.3 \mathrm{~m}$, above which no tritium escapes through this distance and into the atmosphere. Therefore, the minimum anticipated depth of the cover material at USPCI of $1.3 \mathrm{~m}$ (see Sect. 2.2.3) is not used in the analysis. If this cover depth were used, RESRAD would calculate a dose of zero since more time is needed for the cover to erode away than for the tritium to radioactively decay to a negligible dose.

The inhalation rate for the public is assumed to be $8400 \mathrm{~m}^{3} / \mathrm{y}$, which is a weighted sum of a human's resting and light exercise inhalation rates (ICRP 1994). The dose conversion factor is assumed to be $96 \mathrm{rem} / \mathrm{Ci}$, accounting for inhalation and absorption (EPA 1988, ICRP 1979). The annual dose represented over time is shown in Fig. 3.1. The maximum public dose of $1.2 \times 10^{-5} \mathrm{mrem} / \mathrm{y}$ occurs after about 14 years. The dose initially increases with time as the cover is eroding. However, after approximately 14 years, the dose begins to decrease with time due to the radioactive decay of tritium and other source-reducing factors (e.g., leaching). Note that this analysis assumes a thinner cap than would be placed on the waste at USPCI. If the dose were modeled with the appropriate cap depth, there also would be virtually no exposure. Appendix A lists the specific input parameters used by the RESRAD code to calculate the public doses and also presents the output. 


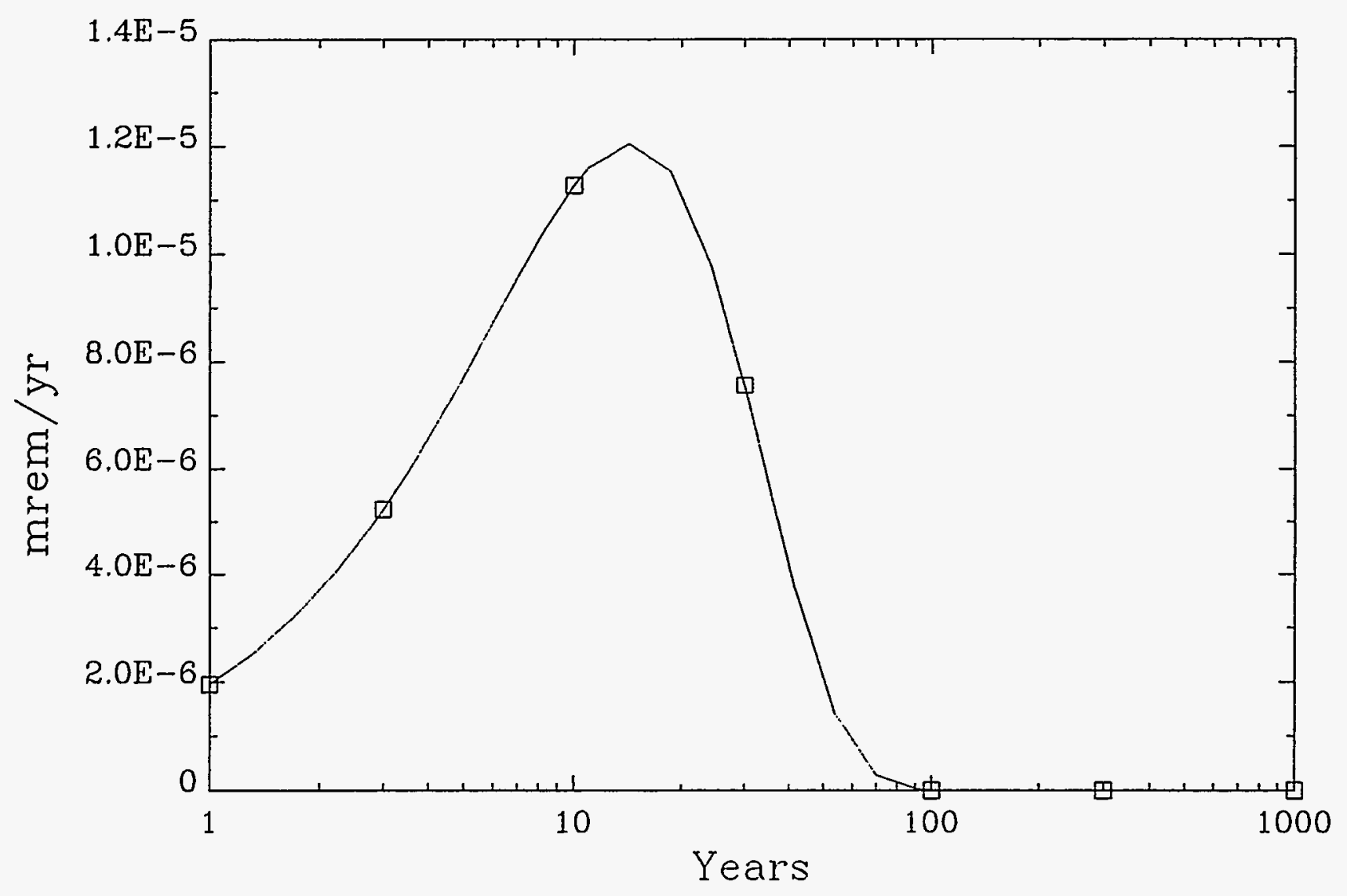

Fig. 3.1. Public Dose from Inhalation of Tritium. 


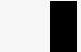




\section{DISCUSSION OF RESULTS}

\subsection{Summary of Results}

The results of this upper-bound dose assessment reveal extremely low annual doses (Table 4.1). The conservative assumptions made throughout the analyses lead to overestimates of dose. The following are some of the major conservative assumptions:

- For the worker exposure scenarios, the dose conversion factor used assumes $50 \%$ of the inhaled dose is absorbed through the skin. However, the use of personal protective equipment would reduce the surface area of exposed skin and thus the amount of tritium absorbed through the skin.

- For stabilization activities, one load of waste was assumed to be stabilized at a time, instead of two loads being mixed and stabilized together.

- For the burial worker exposure scenario, no additional waste or cover is assumed to be placed on top of the Pinellas waste for a year and the worker is assumed to spend nine hours of every working day for a year above the RCRA cell that would contain the Pinellas waste.

- For the burial worker and the public exposure scenarios, the evapotranspiration coefficient is assumed to be the maximum of 1.0. By reducing the coefficient to 0.5 , the doses calculated by the RESRAD code would only be reduced by a factor of about six.

- For the public exposure scenario, a member of the public is assumed to stand above the buried waste $100 \%$ of the time inhaling water vapor contaminated with tritium. This ignores institutional controls, which are required by the RCRA permit for 30 years. Furthermore, the facility is likely to continue to operate for 30 to 50 more years before closure. Therefore, public access would not occur until 60 to 80 years after the waste was placed in the landfill. The dose assessment also ignores the designation of the West Desert Hazardous Industry Area, which precludes residential housing in this area and may restrict access.

- For the public exposure scenario, the assumption of a $0.3 \mathrm{~m}$ cover results in higher doses than expected since the cover would be at least $1.3 \mathrm{~m}(4.3 \mathrm{ft})$ thick.

\subsection{Comparison to Background and Regulatory Limits}

The doses calculated in this analysis are compared to background levels and existing regulatory limits. The average background dose from all sources of radiation to a U.S. 
Table 4.1 Summary of radiological doses

\begin{tabular}{|c|c|c|c|}
\hline Exposure scenario & Dose $(\mathrm{mrem} / \mathrm{y})^{a}$ & $\begin{array}{l}\text { Fraction of natural } \\
\text { background }^{b}\end{array}$ & $\begin{array}{l}\text { Fraction of regulatory } \\
\text { limit }^{c}\end{array}$ \\
\hline Waste sampling & $4.7 \times 10^{-6}$ & $1.6 \times 10^{-8}$ & $9.4 \times 10^{-10}$ \\
\hline Waste stabilization & $6.0 \times 10^{-6}$ & $2.0 \times 10^{-8}$ & $1.2 \times 10^{-9}$ \\
\hline Waste burial & $9.8 \times 10^{-4}$ & $3.3 \times 10^{-6}$ & $2.0 \times 10^{-7}$ \\
\hline Public exposure $e^{d}$ & $1.2 \times 10^{-5}$ & $4.0 \times 10^{-8}$ & $1.2 \times 10^{-6}$ \\
\hline \multicolumn{4}{|c|}{$\begin{array}{l}{ }^{a} \text { Waste sampling and waste stabilization are from short-term exposure scenarios that occur within one } \\
\text { year. Because the doses are so low, no acute radiation effects are anticipated. Therefore, the most reasonable } \\
\text { comparison is to annual background and annual occupational dose levels. The waste burial and public exposure } \\
\text { scenarios are from longer-term exposures that are also compared to annual background and annual occupational } \\
\text { doses. } \\
{ }^{b} \text { Annual average individual natural background level is } 300 \mathrm{mrem} \text {. } \\
{ }^{c} \text { Occupational limit }=5000 \mathrm{mrem} / \mathrm{y} \text {; public limit }=10 \mathrm{mrem} / \mathrm{y} \text {. } \\
{ }^{d} \text { Peak annual exposure occurs about } 14 \text { years after placement of waste. }\end{array}$} \\
\hline
\end{tabular}

individual is about $360 \mathrm{mrem} / \mathrm{y}$. The contribution of natural sources is about $300 \mathrm{mrem} / \mathrm{y}$ (NCRP 1987). The Nuclear Regulatory Commission (NRC) and DOE annual occupational dose limits are both 5,000 mrem (NRC 1995, DOE 1989). The NRC dose limit for protection of the public from all sources and all pathways combined is $100 \mathrm{mrem} / \mathrm{y}$ (NRC 1995). The Clean Air Act National Emissions Standards for Hazardous Air Pollutants (NESHAPs) require the public dose from all exposure pathways due to air emissions be below $10 \mathrm{mrem} / \mathrm{y}$. Since air emissions are the only releases applicable to waste operations at the USPCI facility in Tooele, Utah, the more restrictive NESHAP is used for comparison to the public dose.

The worker doses from sampling, stabilization, and waste burial, and the public dose from inhalation of tritium are presented in Table 4.1. All the predicted doses are far below the natural background levels and the applicable regulatory limits. The percents of the natural background and of the regulatory limits for each scenario are also presented in Table 4.1. The worker doses from waste operations are 310 thousand to 64 million times less than radiation doses from natural sources and 5.1 million to 1.1 billion times less than the regulatory limit. The total public dose is 25 million times less than natural background and 830 thousand times less than the NESHAP limit. Therefore, despite the conservative assumptions about the potentially maximally exposed individuals, the doses are well below the regulatory limits, as well as being only a very small fraction of the average U.S. background levels. 


\subsection{Health Effects}

The health effect associated with low-dose exposures to radiation is cancer. The risk of excess cancer fatalities has been quantified based on atomic bomb exposure data in which large doses of radiation were received. To determine cancer risks at low doses, a common assumption is that exposure to a carcinogen and the development of cancer follow a linear, nothreshold dose-response relationship. The International Commission on Radiological Protection (ICRP) used the atomic bomb exposure data to estimate excess cancer risks per unit dose due to chronic, low dose exposures. These conversion factors for workers and the public are $4 \times 10^{-4}$ and $5 \times 10^{-4}$ excess risk/rem, respectively. Despite the linear, no-threshold assumption, the ICRP cautions against using the cancer risk conversion factors for such low doses as those presented in this analysis. Therefore, although this assessment does not specifically quantify the cancer risk, the risk would be far below $1 \times 10^{-7}$ or any risk level of concern. As discussed in Sect. 3.2, the public dose is virtually zero, emphasizing the point that there is no cancer risk of concern. 



\section{REFERENCES}

DOC (U. S. Department of Commerce) 1995. Statistical Abstract of the United States 1995, 115th Edition, Washington, DC, September.

DOE (U. S. Department of Energy) 1989, Department of Energy Order 5480.11, "Radiation Protection for Occupational Workers."

EPA (U. S. Environmental Protection Agency) 1988. Limiting Values of Radionuclide In Intake and Air Concentration and Dose Conversion Factors for Inhalation, Submersion, and Ingestion. Federal Guidance Report No. 11. EPA-520/1-88-020, Office of Radiation Programs, Washington, DC, September.

EPA (U. S. Environmental Protection Agency) 1987. "Technical Guidance for Hazardous Analysis, Emergency Planning for Extremely Hazardous Substances," U. S. Environmental Protection Agency, Federal Emergency Management Agency, and U.S. Department of Transportation, Washington, DC.

ICRP (International Commission on Radiological Protection) 1994. Annals of the ICRP, "Human Respiratory Tract Model for Radiological Protection, " ICRP Publication 66, Pergamon Press, NY.

ICRP (International Commission on Radiological Protection) 1979. "Limits of Intakes of Radionuclides by Workers," International Commission on Radiological Protection, ICRP Publication 30, Pergamon Press, NY.

M.H. Chew \& Associates, Inc. 1994. Radiological Dose Assessment of Department of Energy Pinellas Plant Waste sent to Laidlaw Environmental Services, Inc., Pinewood, SC. U. S. Department of Energy, Office of Environmental Restoration and Waste Management. June.

NCRP (National Council on Radiation Protection and Measurements) 1987. "Exposure of the Population in the United States and Canada from Natural Background Radiation," NCRP Report No. 94, Bethesda, MD.

NRC (U. S. Nuclear Regulatory Commission) 1995. "Standards for Protection Against Radiation," 10 Code of Federal Regulations, Part 20, Subparts C and D, U.S. Regulatory Commission, Washington, DC.

NRC (U.S. Nuclear Regulatory Commission) 1993. Final Environmental Impact Statement to Construct and Operate a Facility to Receive, Store, and Dispose of 11e.(2) Byproduct Material Near Clive, Utah. Docket No. 40-8989. NUREG-1476, Envirocare of Utah, Inc. U.S. Nuclear Regulatory Commission. Office of Nuclear Materials Safety and Safeguards. August. 
Strock, C. and R. L. Koral 1965. Handbook of Air Conditioning and Ventilating, 2nd Ed. Industrial Press, New York. In M. H. Chew \& Associates 1994.

Yu, C., A. J. Zielen, J. J. Cheng, Y. C. Yuan, L. G. Jones, D. J. LePoire, Y. Y. Want, C. O. Loureiro, E. Gnanapragasam, E. Faillance, A. Wallo III, W. A. Williams, and H. Peterson 1993. Manual for Implementing Residual Radioactive Material Guidelines Using RESRAD, Version 5.05 (ANL/EAD/LD-2, Working Draft for comment, September 1993). 
APPENDIX A

RESRAD VERSION 5.60 INPUT PARAMETERS AND DOSE SUMMARY 
A.1 BURIAL WORKER SCENARIO 
RESRAD, Version $5.60 \quad T^{\prime \prime}$ Limit $=0.5$ year Surmary : Utah burial worker
09/22/95 11:12 Page 3

File: UTAH.OCC

Site-Specific Parameter Surmary

\begin{tabular}{|c|c|c|c|c|c|c|}
\hline & no- & - User & & - Used & by RESRAD & - Parameter \\
\hline Menu & Parameter & Input & - Default & - CIf differen & t from user input) & Name \\
\hline & éáááááááááááááááááááááááááááááááááááááááááááááááááááááá & iáéááááááááááa & & & & $\mathbf{1 a ̆}$ \\
\hline R011 & - Area of contaminated zone $\left(m^{\star \star} 2\right)$ & $\circ 2.450 E+01$ & $\circ 1.000 E+04$ & $\circ$ & $\cdots$ & - AREA \\
\hline R011 & - Thickness of contaminated zone $(\mathrm{m})$ & $\cdot 5.800 E+00$ & $\cdot 2.000 E+00$ & $\circ$ & --- & - THICKO \\
\hline R011 & - Length parallel to aquifer flow (m) & - not used & - $1.000 E+02$ & $\circ$ & $-\cdot$ & - LCZPAQ \\
\hline R011 & - Basic radiation dose limit (mrem/yr) & $\cdot 3.000 E+01$ & - 3.000E+01 & - & $\cdots$ & $\circ$ BRDL \\
\hline R011 & - Time since placement of material (yr) & $\circ 0.000 E+00$ & $0.000 E+00$ & $\circ$ & $\cdots$ & $\circ \mathrm{TI}$ \\
\hline R011 & - Times for calculations $(y r)$ & - $1.000 E+00$ & $1.000 E+00$ & 0 & --- & - $T(2)$ \\
\hline R011 & - Times for calculations (yr) & $\circ 3.000 E+00$ & $.3 .000 E+00$ & $\circ$ & $\cdots$ & - $T(3)$ \\
\hline R011 & - Times for calculations (yr) & $\cdot 1.000 E+01$ & $\circ 1.000 E+01$ & $\circ$ & $\cdots$ & - $T(4)$ \\
\hline R011 & - Times for calculations (yr) & $\cdot 3.000 E+01$ & - $3.000 E+01$ & $\cdot$ & $\therefore-$ & - $T(5)$ \\
\hline R011 & - Times for calculations (yr) & - $1.000 E+02$ & $01.000 E+02$ & 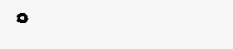 & --- & - $T(6)$ \\
\hline R011 & - Times for calculations (yr) & $\circ 3.000 E+02$ & $\circ 3.000 E+02$ & $\circ$ & $\cdots$ & - $T(7)$ \\
\hline R011 & - Times for calculations (yr) & $\cdot 1.000 E+03$ & $\cdot 1.000 E+03$ & $\circ$ & $\cdots$ & - $\mathrm{T}(\mathrm{8})$ \\
\hline $\mathrm{R} 011$ & - Times for calculations (yr) & - not used & $0.000 E+00$ & $\circ$ & $--\cdot$ & - $T(9)$ \\
\hline R011 & - Times for calculations $(y r)$ & - not used & $\begin{array}{l}-0.000 E+00 \\
.\end{array}$ & $\begin{array}{l}\circ \\
\circ\end{array}$ & -- & - $T(10)$ \\
\hline R012 & - Initial principal radionuclide $(\mathrm{pci} / \mathrm{g}): H-3$ & $\circ 2.834 E+01$ & $\cdot 0.000 E+00$ & $\circ$ & $-\cdot-$ & - $s 1(1)$ \\
\hline R012 & - Concentration in groundwater $(\mathrm{pC} i / \mathrm{L}): \mathrm{H}-3$ & - not used & . $0.000 E+00$ & $\begin{array}{l}0 \\
0\end{array}$ & -- & - WI( 1) \\
\hline R013 & - Cover depth (m) & $\circ 0.000 E+00$ & $0.000 E+00$ & - & $\cdots$ & - COVERO \\
\hline R013 & - Density of cover material $\left(\mathrm{g} / \mathrm{cm}^{\star \star} 3\right)$ & - not used & - $1.500 E+00$ & 0 & $\cdots$ & - DENSCV \\
\hline$R 013$ & - Cover depth erosion rate $(m / y r)$ & - not used & - $1.000 E-03$ & - & $\cdots$ & - vCV \\
\hline R013 & - Density of contaminated zone $\left(\mathrm{g} / \mathrm{cm}^{\star * 3}\right)$ & - $1.150 E+00$ & $\circ 1.500 E+00$ & $\circ$ & $-\cdot-$ & - DENSCZ \\
\hline$R 013^{\circ}$ & - Contaminated zone erosion rate $(m / y r)$ & - 1.000 E-03 & $.1 .000 E-03$ & $\circ$ & $\cdots$ & - vCZ \\
\hline R013 & - Contaminated zone total porosity & - 3.000E-01 & - 4.000E-01 & - & $\cdots$ & - TPCZ \\
\hline$R 013^{\circ}$ & - Contaminated zone effective porosity & $.3 .000 \mathrm{E}-01$ & - 2.000E-01. & $\circ$ & $--\cdot$ & - EPCZ \\
\hline $\mathrm{R} 013^{\circ}$ & - Contaminated zone hydraulic conductivity (m/yr) & $.1 .000 E+01$ & $01.000 E+01$ & - & $\cdots$ & - $\mathrm{HCCZ}$ \\
\hline R013 & - Contaminated zone b parameter & - $5.300 E+00$ & - $5.300 E+00$ & $\circ$ & -- & $\circ \mathrm{BCZ}$ \\
\hline $\mathrm{R} 013^{\circ}$ & - Humidity in air $\left(\mathrm{g} / \mathrm{cm}^{\star \star} 3\right)$ & - $4.700 E+00$ & $8.000 E+00$ & - & -- & - HUMID \\
\hline R013 & - Evapotranspiration coefficient & - $9.990 \mathrm{E}-01$ & - 5.000E-01 & $\circ$ & $-\cdot-$ & - EVAPTR \\
\hline $\mathrm{R013}$ & - Precipitation $(m / y r)$ & - $1.300 \mathrm{E}-01$ & $01.000 \mathrm{E}+00$ & $\circ$ & $\cdots$ & - PRECIP \\
\hline R013 & - Irrigation (m/yr) & $0.000 E+00$ & $02.000 E-01$ & $\cdot$ & --- & - RI \\
\hline$R 013^{\circ}$ & - Irrigation mode & - overhead & - overhead & $\circ$ & $\cdots$ & - IDITCH \\
\hline R013 & - Runoff coefficient & $02.000 E-01$ & $.2 .000 E-01$ & $\cdot$ & $-\cdots$ & - RUNOFF \\
\hline R013 & - Hatershed area for nearby stream or pond $\left(m^{*} 2\right)$ & - not used & $01.000 E+06$ & - & $\cdots$ & - WAREA \\
\hline R013 & - Accuracy for water/soil computations & - not used & $\begin{array}{l}-1.000 E-03 \\
.\end{array}$ & Zero shows & Simpson's rule. & - EPS \\
\hline $\mathrm{R} 014^{\circ}$ & - Density of saturated zone $\left(\mathrm{g} / \mathrm{cm}^{* * 3}\right)$ & - not used & - $1.500 E+00$ & - & $\cdots$ & - DENSAQ \\
\hline $8014^{\circ}$ & - Saturated zone total porosity & - not used & - 4.000E-01 & 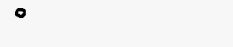 & $\cdots$ & - TPSZ \\
\hline$R 014^{\circ}$ & - Saturated zone effective porosity & - not used & - 2.000E-01 & $\cdot$ & -- & - EPSZ \\
\hline R014. & - Saturated zone hydraulic conductivity (m/yr) & - not used & $.1 .000 E+02$ & $\circ$ & $\cdots$ & - HCSZ \\
\hline $\mathrm{R} 014^{\circ}$ & - Saturated zone hydraulic gradient & - not used & $.2 .000 E-02$ & $\circ$ & $\cdots$ & - HGWT \\
\hline R014 ${ }^{\circ}$ & - Saturated zone b parameter & ${ }^{\circ}$ not used & - $5.300 \mathrm{E}+00$ & $\cdot$ & $\cdots$ & - BSZ \\
\hline R014 ${ }^{\circ}$ & - Water table drop rate $(m / y r)$ & - not used & $.1 .000 \mathrm{E}-03$ & - & $\cdots$ & - VWT \\
\hline $\mathrm{R} 014^{\circ}$ & - Well pump intake depth (m below water table) & ${ }^{\circ}$ not used & $\cdot 1.000 E+01$ & $\circ$ & -- & - DWIBWT \\
\hline $\mathrm{R} 014^{\circ}$ & - Model: Nondispersion (ND) or Mass-Balance (MB) & ${ }^{\circ}$ not used & $\circ \mathrm{ND}$ & $\circ$ & $\cdots$ & $\circ$ MODEL \\
\hline $\mathrm{R}_{014^{\circ}}^{\circ}$ & - Well pumping rate $\left(m^{* * 3 / y r)}\right.$ & - not used & - $2.500 E+02$ & $\begin{array}{l}\circ \\
\circ\end{array}$ & --- & - UW \\
\hline R015 ${ }^{\circ}$ & - Number of unsaturated zone strata & - not used & $\circ 1$ & - & $\cdots$ & - NS \\
\hline
\end{tabular}


RESRAD, Version $5.60 \quad T^{*}$ Limit $=0.5$ year Sumary : Utah burial worker
09/22/95 11:12 Page 4

File: UTAH.OCC

Site-Specific Parameter Sumary (continued)

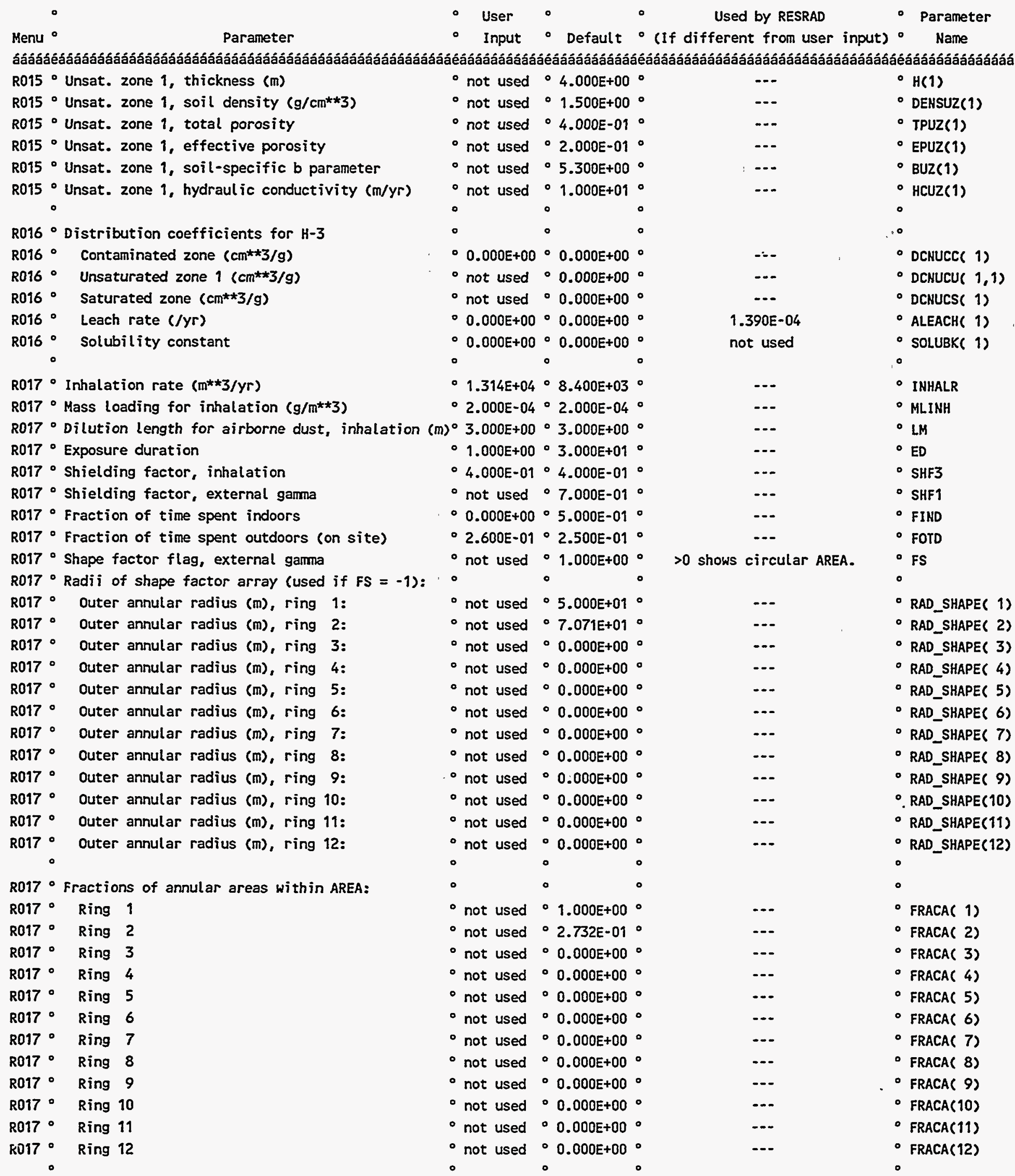


RESRAD, Version $5.60 \quad T *$ Limit $=0.5$ year

Surmary : Utah burial worker
09/22/95 11:12 Page 5

File: UTAH.OCC

Site-Specific Parameter Sumary (continued)

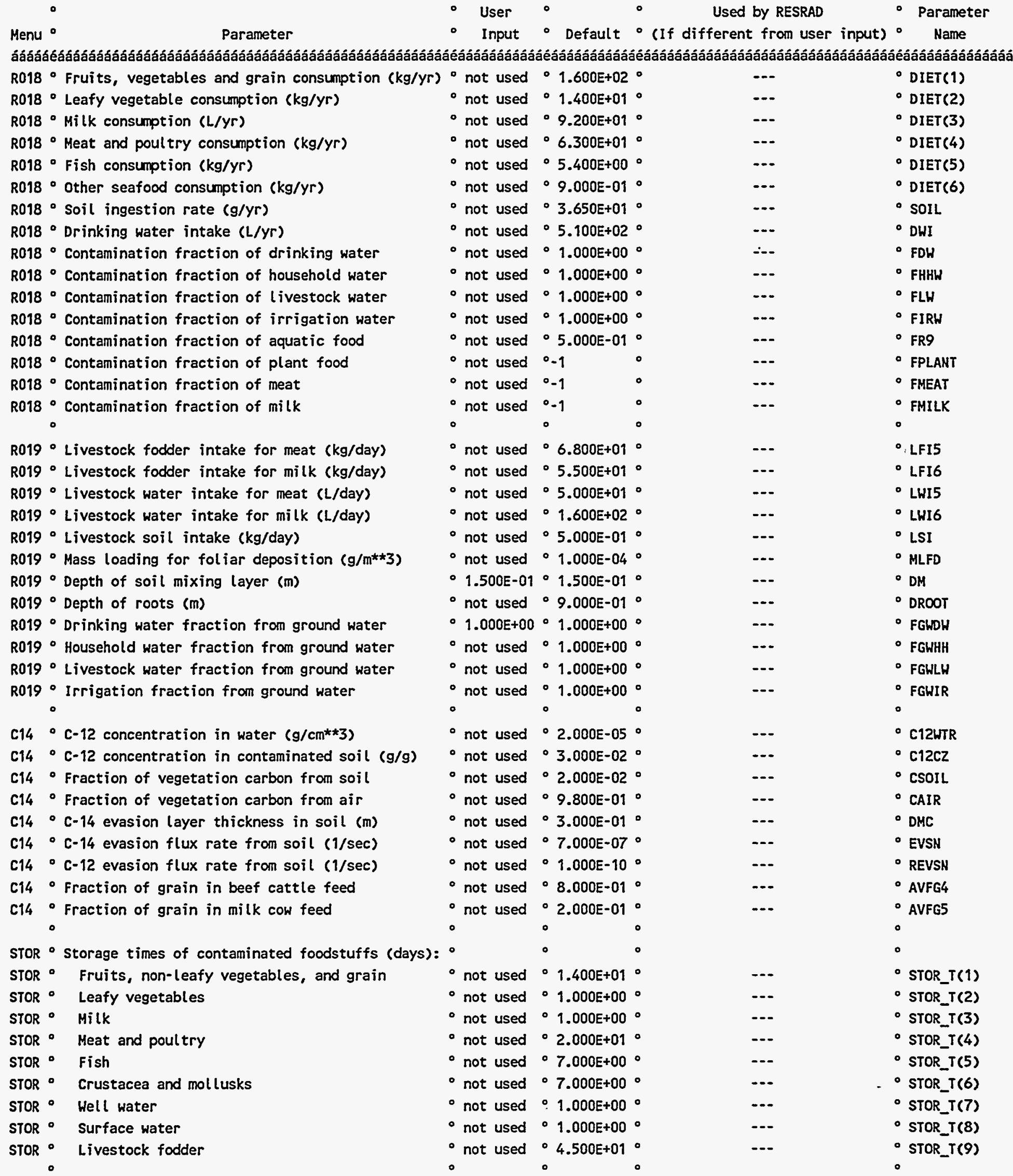


RESRAD, Version $5.60 \quad T^{*}$ Limit $=0.5$ year Sumary : Utah burial worker
09/22/95 11:12 Page 6

File: UTAH.OCC

Site-Specific Parameter Summary (continued)

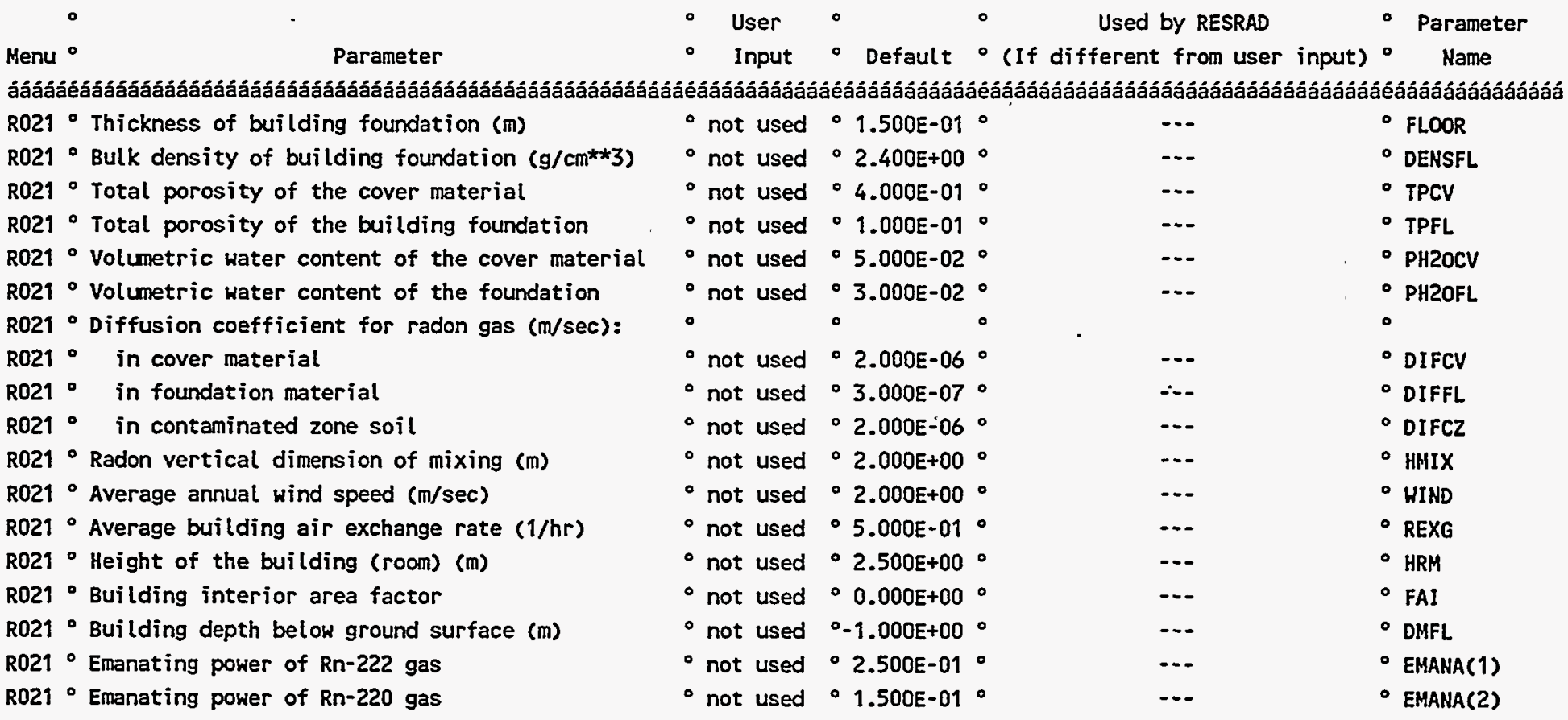

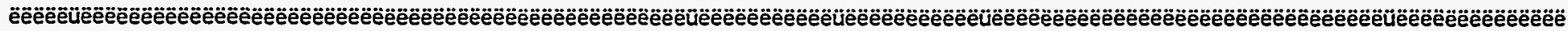

\begin{tabular}{|c|c|c|}
\hline \multicolumn{3}{|c|}{ Sumary of Pathway Selections } \\
\hline Pathway & $\circ$ & User Selection \\
\hline \multicolumn{3}{|c|}{ 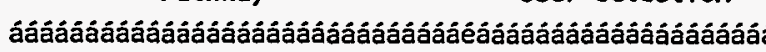 } \\
\hline 1 -- external gamma & $\circ$ & suppressed \\
\hline 2 -- inhalation $(w / 0$ & & active \\
\hline 3 -- plant ingestion & $\circ$ & suppressed \\
\hline 4 -- meat ingestion & $\circ$ & suppressed \\
\hline 5 -. milk ingestion & - & suppressed \\
\hline 6 - aquatic foods & $\circ$ & suppressed \\
\hline 7 -- drinking water & - & suppressed \\
\hline 8 -- soil ingestion & $\circ$ & suppressed \\
\hline 9 -- radon & $\circ$ & suppressed \\
\hline
\end{tabular}


RESRAD, Version $5.60 \quad T$.* Limit $=0.5$ year sumary : Utah burial worker

Contaminated Zone Dimensions ảááááááááááááááááááááááááá

Area: $\quad 24.50$ square meters

Thickness: $\quad \mathbf{5 . 8 0}$ meters

Cover Depth: $\quad 0.00$ meters
09/22/95 11:12 Page 7

File: UTAH.OCC
Initial Soil Concentrations, pci/g

áááááááááááááááááááááááááááááááá

$\mathrm{H}-3$

$2.834 E+01$

Total Dose TDOSE( $t$ ), mrem/yr

Basic Radiation Dose Limit $=30 \mathrm{mrem} / \mathrm{yr}$

Total Mixture Sum $M(t)=$ Fraction of Basic Dose Limit Received at Time $(t)$

aááááááááááááááááááááááááááááááááááááááááááááááááááááááááááááăááááááááááá

$t$ (years): $\begin{array}{llllllll}0.000 E+00 & 1.000 E+00 & 3.000 E+00 & 1.000 E+01 & 3.000 E+01 & 1.000 E+02 & 3.000 E+02 & 1.000 E+03\end{array}$

TDOSE $(t): \quad 9.756 E-04 \quad 8.024 E-04 \quad 5.427 E-04 \quad 1.379 E-04 \quad 2.715 E-06 \quad 2.493 E-12 \quad 0.000 E+00 \quad 0.000 E+00$

$H(t): \quad 3.252 E-05 \quad 2.675 E-05 \quad 1.809 E-05 \quad 4.597 E-06 \quad 9.052 E-08 \quad 8.309 E-14 \quad 0.000 E+00 \quad 0.000 E+00$

Maximum TDOSE(t): $9.756 E-04 \mathrm{mrem} / \mathrm{yr}$ at $t=0.000 E+00$ years 
A.2 PUBLIC DOSE SCENARIO 
RESRAD, Version 5.60

Summary : utah
$T^{*}$ Limit $=0.5$ year

09/22/95 11:22 Page 3

File: UTAH.DAT

Site-Specific Parameter Sumary

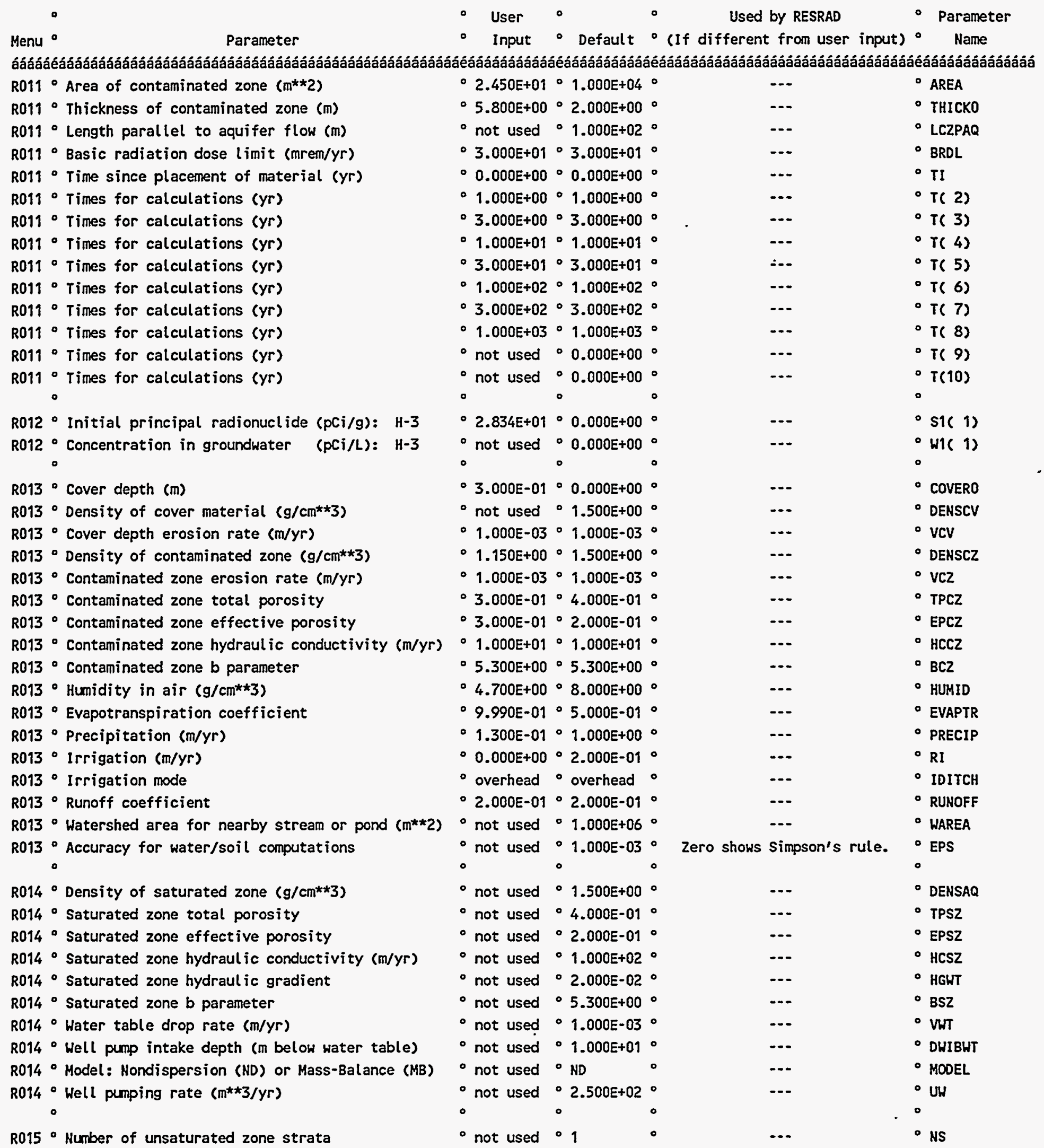


Site-Specific Parameter Sumary (continued)

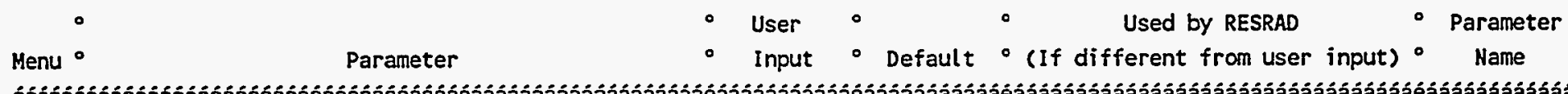

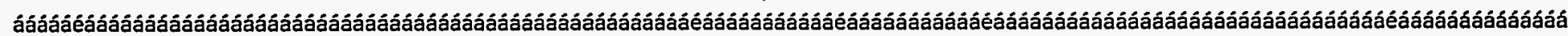

R015 - Unsat. zone 1, thickness (m)

R015 Unsat. zone 1, soil density $\left(\mathrm{g} / \mathrm{cm}^{\star \star} 3\right)$

R015 - Unsat. zone 1, total porosity

R015 - Unsat. zone 1, effective porosity

R015 ${ }^{\circ}$ Unsat. zone 1, soil-specific b parameter

R015 - Unsat. zone 1, hydraulic conductivity $(\mathrm{m} / \mathrm{yr})$

R016 Distribution coefficients for $\mathrm{H}-3$

R016 - Contaminated zone $\left(\mathrm{cm}^{\star *} 3 / \mathrm{g}\right)$

R016 - Unsaturated zone $1\left(\mathrm{~cm}^{\star \star} / \mathrm{g} / \mathrm{g}\right)$

R016 - Saturated zone $\left(\mathrm{cm}^{\star *} 3 / \mathrm{g}\right)$

R016 - Leach rate (/yr)

R016 - Solubility constant

R017 Inhalation rate $\left(m^{* * 3 / y r)}\right.$

R017 Mass loading for inhalation $\left(\mathrm{g} / \mathrm{m}^{\star * 3}\right)$

- not used $\circ$ 4.000E+00

- not used $1.500 E+00^{\circ}$

- not used $\circ$ 4.000E-01 $\circ$

- not used $2.000 E-01^{\circ}$

- not used $\circ 5.300 E+00^{\circ}$

- not used $1.000 E+01$.

R017 Exposure duration

R017 Shielding factor, inhalation

R017 Shielding factor, external gama

R017 Fraction of time spent indoors

R017 Fraction of time spent outdoors (on site)

R017 - Shape factor flag, external gama

R017 Radii of shape factor array (used if FS = -1):

R017 ${ }^{\circ}$ Outer annular radius (m), ring 1:

R017 O Outer annular radius (m), ring 2:

R017 - Outer annular radius (m), ring 3:

R017 - Outer annular radius (m), ring 4:

R017 - Outer annular radius (m), ring 5:

R017 O Outer annular radius (m), ring 6:

R017 - Outer annular radius (m), ring 7:

R017 - Outer annular radius (m), ring 8:

R017 - Outer annular radius (m), ring 9:

R017 O Outer annular radius (m), ring 10:

R017 $7^{\circ}$ Outer annular radius (m), ring 11:

R017 Outer annular radius (m), ring 12:

R017 Fractions of annular areas within AREA:

R017 $7^{\circ}$ Ring 1

R017 $7^{\circ}$ Ring 2

R017 $7^{\circ}$ Ring 3

R017 * Ring 4

R017 * Ring 5

R017 $\circ$ Ring 6

R017 $7^{\circ}$ Ring 7

R017 $7^{\circ}$ Ring 8

R017 * Ring 9

R017 * Ring 10

R017 $7^{\circ}$ Ring 11

R017 * Ring 12$$
\text { - } 0 \text { o }
$$$$
\circ 0.000 E+00 \circ 0.000 E+00^{\circ}
$$

- not used $\circ .000 E+00^{\circ}$

- not used $0.000 E+00$.

- 0.000e+00 0.000e+00。

- $0.000 E+00^{\circ} 0.000 E+00^{\circ}$

$\circ$

- 8.400E+03 $8.400 E+03^{\circ}$

- 2.000E-04⒉000E-04。

$\circ 3.000 E+00 \circ 3.000 E+00 \circ$

- 3.000E+01 $3.000 E+01^{\circ}$

- 4.000E-01 4.000E-01०

- not used ० 7.000E-01

- 0.000e+00 $\circ$ 5.000e-01 0

- 1.000E+00 $\circ 2.500 E-01 \circ$

- not used $\triangle 1.000 E+00^{\circ}$

-

- not used $\circ 5.000 E+01^{\circ}$

- not used $\circ 7.071 E+01^{\circ}$

- not used $0.000 E+00^{\circ}$

- not used $0.000 E+00^{\circ}$

- not used $0.000 E+00^{\circ}$

- not used $\circ 0.000 E+00^{\circ}$

- not used $0.000 E+00^{\circ}$

- not used $0.000 E+00^{\circ}$

- not used $\circ 0.000 E+00^{\circ}$

- not used $0.000 E+00$.

- not used $0.000 E+00^{\circ}$

- not used $0.000 E+00^{\circ}$

$\circ$

- not used $01.000 E+00^{\circ}$

- not used $\circ 2.732 E-01{ }^{\circ}$

- not used $0.000 E+00$.

- not used $0.000 E+00^{\circ}$

- not used $0.000 E+00 \circ$

- not used $0.000 E+00$.

- not used $0.000 E+00 \circ$

- not used $0.000 E+00$.

- not used $0.000 E+00$.

- not used $0.000 E+00 \circ$

- not used $0.000 E+00 \circ$

- not used 0.000E+00。
- $H(1)$

- DENSUZ(1)

- TPUZ(1)

- EPUZ(1)

- BUZ(1)

- HCUZ(1)

o

。

- DCNucc( 1$)$

- $\operatorname{DCNUCU}(1,1)$

- dCNucse 1 )

- ALEACH( 1)

- $\operatorname{SOLUBK}(1)$

。

- INHALR

- hLINH

- LM

- ED

- SHF3

- SHF1

- FIND

- FOTD

- FS

。

- RAD_SHAPE( 1)

- RAD_SHAPE( 2)

- RAD_SHAPE( 3)

- RAD_SHAPE( 4)

- RAD_SHAPE( 5)

- RAD_SHAPE( 6)

- RAD_SHAPE( 7$)$

- RAD_SHAPE( 8)

- RAD_SHAPE( 9)

- RAD_SHAPE(10)

- RAD_SHAPE(11)

- RAD_SHAPE(12)

-

。

- fracal 1)

- fracal 2)

- fRAca( 3)

- fracal 4)

- fracal 5)

- fracal 6)

- fraca( 7$)$

- fracal 8)

- fracal 9)

- fRACA(10)

- fraca(11)

- fraca(12) 
RESRAD, Version 5.60

Surmary : utah $\tau^{*}$ Limit $=0.5$ year

09/22/95 11:22 Page 5

File: UTAH.DAT

Site-Specific Parameter Sumary (continued)

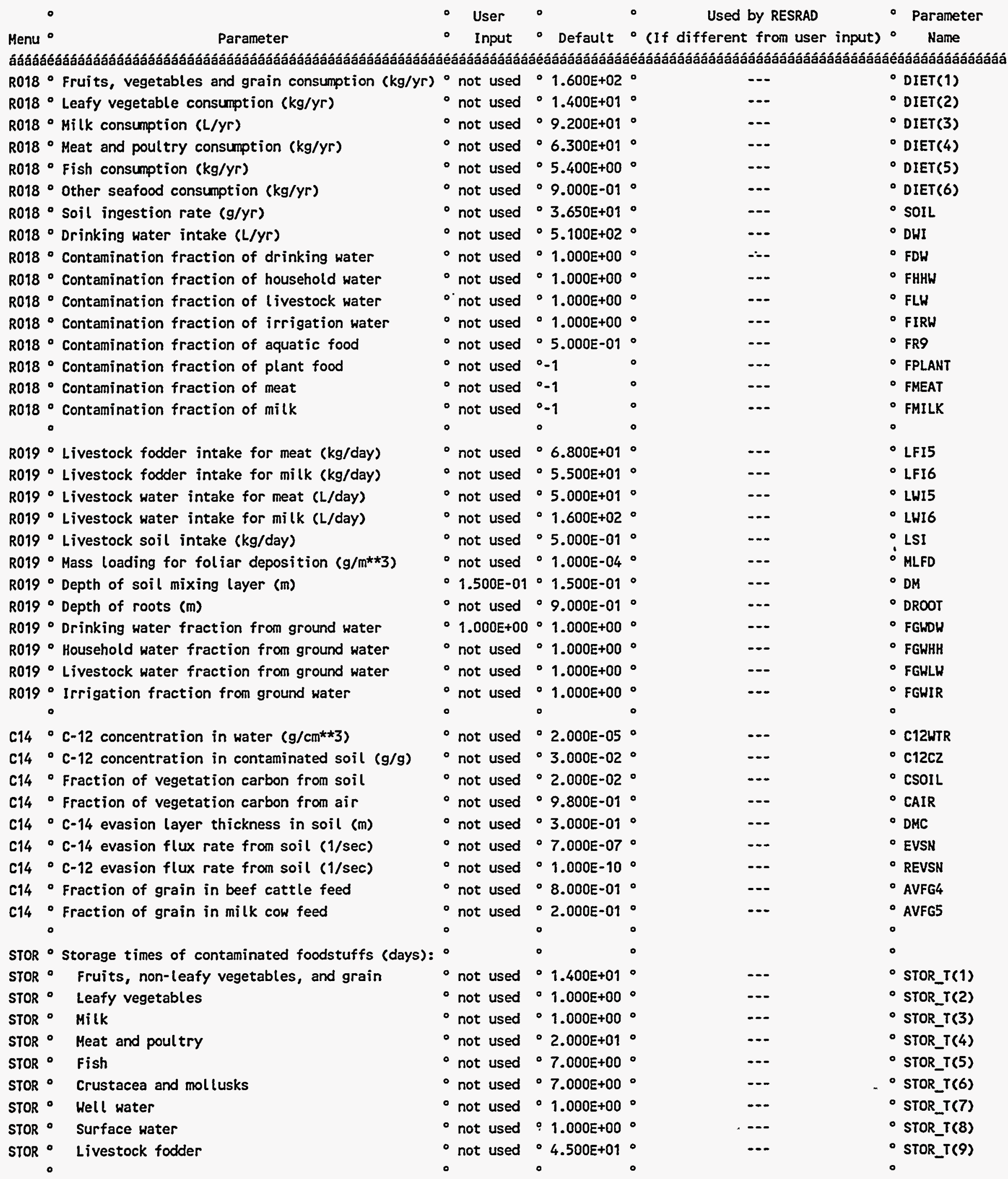




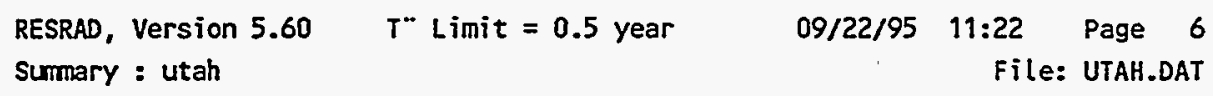

Site-Specific Parameter Sumary (continued)

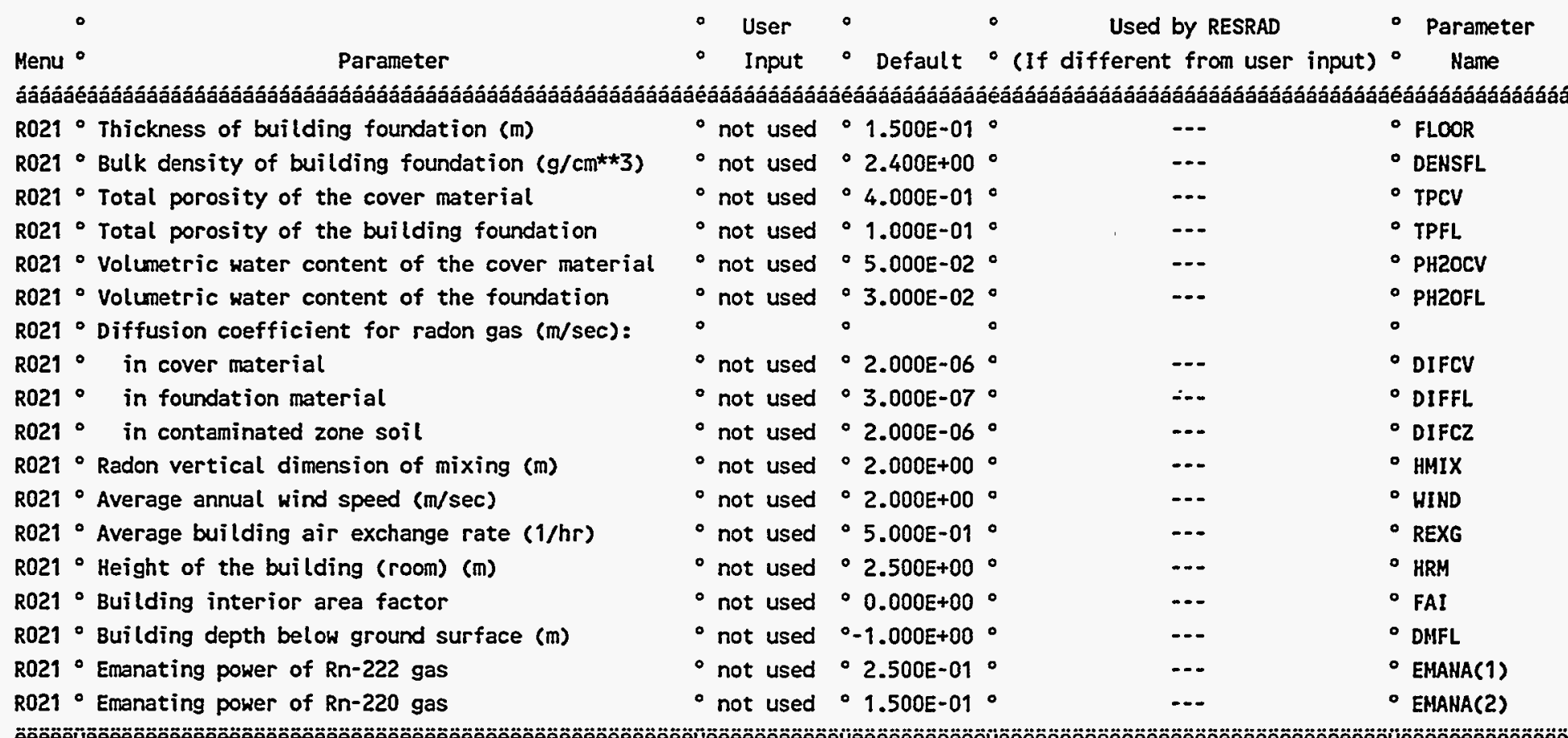

Summary of Pathway Selections

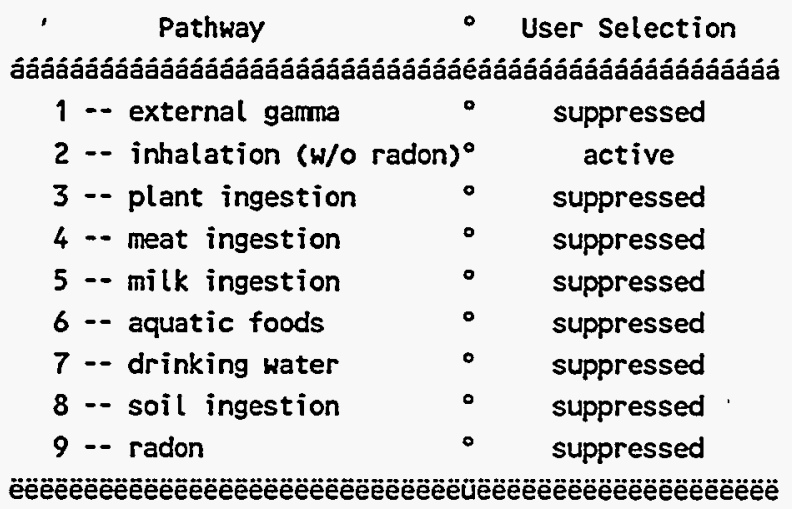




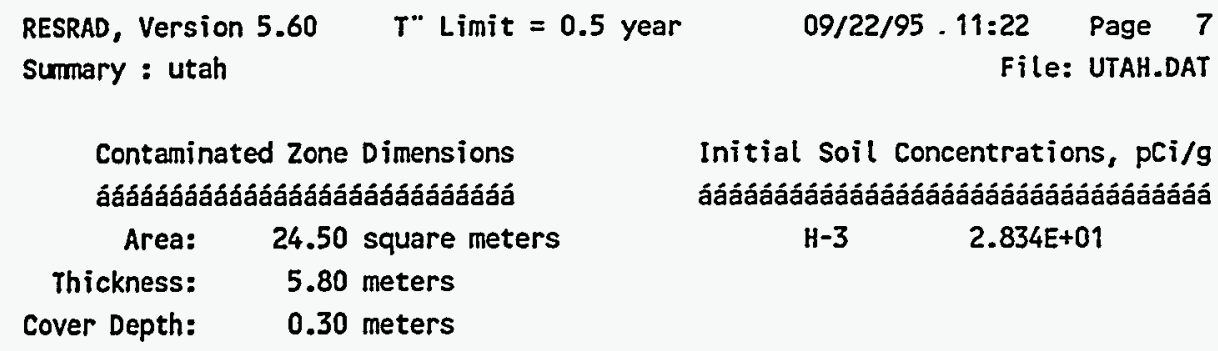

Total Dose $\operatorname{TDOSE}(t), \mathrm{mrem} / \mathrm{yr}$

Basic Radiation Dose Limit $=30 \mathrm{mrem} / \mathrm{yr}$

Total Mixture Sum $M(t)=$ Fraction of Basic Dose Limit Received at Time ( $t$ ) ááááááááááááááááááááááááááááááááááááááááááááááááááááááááááááááááááááá

$t$ (years): $\begin{array}{llllllll}0.000 E+00 & 1.000 E+00 & 3.000 E+00 & 1.000 E+01 & 3.000 E+01 & 1.000 E+02 & 3.000 E+02 & 1.000 E+03\end{array}$

TDOSE $(t): \quad 0.000 E+00 \quad 1.960 E-06 \quad 5.235 E-06 \quad 1.128 E-05 \quad 7.564 E-06 \quad 7.186 E-09 \quad 0.000 E+00 \quad 0.000 E+00$

$M(t): \quad \begin{array}{lllllllll}0.000 E+00 & 6.535 E-08 & 1.745 E-07 & 3.759 E-07 & 2.521 E-07 & 2.395 E-10 & 0.000 E+00 & 0.000 E+00\end{array}$

Maximum $\operatorname{TDOSE}(t): 1.206 E-05 \mathrm{mrem} / \mathrm{yr}$ at $t=14.34 \mathrm{p} 0.01$ years

Total Dose Contributions TDOSE(i,p,t) for Individual Radionuclides (i) and Pathways ( $p$ ) As mrem/yr and Fraction of Total Dose At $t=14.34$ years

Water Independent Pathways (Inhalation excludes radon)

\begin{tabular}{|c|c|c|c|c|c|c|c|}
\hline & Ground & & & & Meat & & \\
\hline & ááááááááááááááááá & áááááááááááááááá & ááááááááåááá & Ǵáāááááááááá & Gáááảááááá & Iááááááááááá & \\
\hline áááááá & $\begin{array}{l}\text { mrem/yr fract. } \\
\text { ááááááááa áááááá }\end{array}$ & $\begin{array}{l}\text { mrem/yr fract. } \\
\text { ááááááááá áááááá }\end{array}$ & $\begin{array}{l}\text { mrem/yr fract. } \\
\text { ááááááááá áááááá }\end{array}$ & $\begin{array}{l}\text { mrem/yr fract. } \\
\text { ááááááááá áááááá }\end{array}$ & $\begin{array}{l}\text { mrem/yr frac } \\
\text { áááááááááá áááá }\end{array}$ & $\begin{array}{l}\text { mrem/yr fract. } \\
\text { ááááááááá áááááá }\end{array}$ & $\begin{array}{l}\text { mrem/yr f } \\
\text { ááááááááá á }\end{array}$ \\
\hline & & & & & & & \\
\hline & & & & & & & \\
\hline otal & $0.000 E+00 \quad 0.0000$ & $1.206 \mathrm{E}-051.0000$ & $0.000 E+00 \quad 0.0000$ & $0.000 E+00 \quad 0.0000$ & $0.000 E+00 \quad 0.0000$ & $0.000 E+00 \quad 0.0000$ & $0.000 E+00 \quad 0.0000$ \\
\hline
\end{tabular}

Total Dose Contributions TDOSE $(i, p, t)$ for Individual Radionuclides (i) and Pathways ( $p$ ) As mrem/yr and Fraction of Total Dose At $t=14.34$ years

Hater Dependent Pathways

\begin{tabular}{|c|c|c|c|c|c|c|c|}
\hline & Water & Fish & Radon & Plant & Meat & Milk & All Pathways* \\
\hline & áááááááááááá & ááááááááááá & Ǵáâááááá & Gáááááááááááć & áááááááááááá & áááááááá & \\
\hline & $\begin{array}{l}\text { mrem/yr fr } \\
\text { ááááááá áa }\end{array}$ & $\begin{array}{l}\text { mrem/yr fract. } \\
\text { áááááááá áááááá }\end{array}$ & $\begin{array}{l}\text { mrem/yr fract. } \\
\text { ááááááááá áááááá }\end{array}$ & $\begin{array}{c}\text { mrem/yr fr } \\
\text { ááááááááá áá }\end{array}$ & $\begin{array}{l}\text { mrem/yr fract. } \\
\text { ááááááááá áááááá }\end{array}$ & $\begin{array}{l}\text { mrem/yr fract. } \\
\text { ááááááááá áááááá }\end{array}$ & $\begin{array}{l}\text { mren/yr fr } \\
\text { ááááááááá áá }\end{array}$ \\
\hline & OOOE+OOO 0 & $+\infty 00$ & 000 & - 00 & & $=+\infty 00$. & \\
\hline & & & & & & & \\
\hline tal & $0.000 E+00 \quad 0.0000$ & $0.000 E+00 \quad 0.0000$ & $0.000 E+00 \quad 0.0000$ & $0.000 E+00 \quad 0.0000$ & $0.000 E+00 \quad 0.0000$ & $0.000 E+00 \quad 0.0000$ & $1.206 E-05 \quad 1.0000$ \\
\hline
\end{tabular}

*Sun of all water independent and dependent pathways. 


\section{INTERNAL DISTRIBUTION}

1-10. M. L. Socolof

11-12. K. E. Bowman

13. G. E. Courville

14. D. W. Lee

15. D. A. Lombardi

16. C. I. Moser

17. R.M. Reed
18. R. B. Shelton

19. G. P. Zimmerman

20.. ORNL Patent Office

21. Central Research Library

22. Document Reference Section

23-24. Laboratory Records

25. Laboratory Records-RC

\section{EXTERNAL DISTRIBUTION}

26. Dr. Thomas E. Drabek, Professor, Department of Sociology, University of Denver, Denver, CO 80208-0209

27. Dr. Stephen G. Hildebrand, Director, Environmental Sciences Division, Oak Ridge National Laboratory, P.O. Box 2008, Oak Ridge, Tennessee 37831-6037

28. Mr. George F. Sowers, P.E., Senior Vice President, Law Companies Group, Inc., 114 Townpark Drive, Suite 250, Kennesaw, GA 30144-5599

29. Dr. C. Michael Walton, Emest H. Cockrell Centennial Chair in Engineering and Chairman, Department of Civil Engineering, University of Texas at Austin, Austin, Texas $78712-1076$

30. ORNL Site Manager, U.S. Department of Energy, Oak Ridge National Laboratory, P.O. Box 2008, Oak Ridge, Tennessee 37831-6269

31-32. OSTI, U.S. Department of Energy, P.O. Box 62, Oak Ridge, Tennessee 37831 